\title{
A geochemical study of the Sweet Home mine, Colorado Mineral Belt, USA: formation of deep hydrothermal vein-type molybdenum greisen and base metal mineralization
}

\author{
Malte Stoltnow ${ }^{1,2}$ [ $\cdot$ Volker Lüders $^{2} \cdot$ Stefan de Graaf ${ }^{3} \cdot$ Samuel Niedermann $^{2}$
}

Received: 22 September 2021 / Accepted: 16 February 2022 / Published online: 1 March 2022

(c) The Author(s) 2022

\begin{abstract}
Deep hydrothermal Mo, W, and base metal mineralization at the Sweet Home mine (Detroit City portal) formed in response to magmatic activity during the Oligocene. Microthermometric data of fluid inclusions trapped in greisen quartz and fluorite suggest that the early-stage mineralization at the Sweet Home mine precipitated from low- to medium-salinity (1.5-11.5 wt $\%$ equiv. $\mathrm{NaCl}$ ), $\mathrm{CO}_{2}$-bearing fluids at temperatures between 360 and $415{ }^{\circ} \mathrm{C}$ and at depths of at least $3.5 \mathrm{~km}$. Stable isotope and noble gas isotope data indicate that greisen formation and base metal mineralization at the Sweet Home mine was related to fluids of different origins. Early magmatic fluids were the principal source for mantle-derived volatiles $\left(\mathrm{CO}_{2}, \mathrm{H}_{2} \mathrm{~S}_{\mathrm{SO}}\right.$, noble gases), which subsequently mixed with significant amounts of heated meteoric water. Mixing of magmatic fluids with meteoric water is constrained by $\delta^{2} \mathrm{H}_{\mathrm{w}}-\delta^{18} \mathrm{O}_{\mathrm{w}}$ relationships of fluid inclusions. The deep hydrothermal mineralization at the Sweet Home mine shows features similar to deep hydrothermal vein mineralization at Climax-type Mo deposits or on their periphery. This suggests that fluid migration and the deposition of ore and gangue minerals in the Sweet Home mine was triggered by a deep-seated magmatic intrusion. The findings of this study are in good agreement with the results of previous fluid inclusion studies of the mineralization of the Sweet Home mine and from Climax-type Mo porphyry deposits in the Colorado Mineral Belt.
\end{abstract}

Keywords Hydrothermal veins · Fluid inclusion geochemistry $\cdot$ Fluid mixing $\cdot$ Ore deposition $\cdot$ Colorado mineral belt . Molybdenum mineralization

\section{Introduction}

The Colorado Mineral Belt (CMB) hosts a number of economic molybdenum porphyry deposits, such as the worldclass Climax and Urad-Henderson deposits (Fig. 1). The formation of Climax-type Mo deposits in the CMB is related to the emplacement of highly evolved calc-alkaline granitic and subvolcanic rhyolite porphyry melts (e.g., Wallace 1995;

Editorial handling: M. Steele-Macinnis

Malte Stoltnow

mstolt@gfz-potsdam.de

1 Institute of Geosciences, University of Potsdam, Karl-Liebknecht-Straße 24/25, 14476 Potsdam, Germany

2 GFZ German Research Centre for Geosciences, 14473 Telegrafenberg, Germany

3 Max Planck Institute for Chemistry, Hahn-Meitner-Weg 1, 55218 Mainz, Germany
Ludington and Plumlee 2009; Audétat and Li 2017), which are part of bimodal magmatism related to crustal extension during the Mid- to Late Cenozoic (e.g., Lipman and Mehnert 1975; Westra and Keith 1981; White et al. 1981; Bookstrom et al. 1988; Carten et al. 1993; Keith et al. 1993; Russell and Snelson 1994; Ludington and Plumlee 2009; Audétat 2010; Audétat et al. 2011; Mercer et al. 2015).

Climax-type deposits have high $\mathrm{Mo}$ and little $\mathrm{Cu}$ enrichment. The ore is concentrated in ore shells that consist of stockwork vein and greisen molybdenite-fluorite-quartz-pyrite-topaz-sericite mineralization accompanied by intense host rock alteration (e.g., Audétat and Li 2017 and references therein; ESM Fig. 1). The main Mo mineralization occurs at the flanks and apical parts of small porphyry stocks. Multiple intrusions lead to different overlapping ore shells and individual Climax-type deposits (Wallace et al. 1968; Mutschler et al. 1981; White et al. 1981; Bookstrom 1989; Carten et al. 1993; Wallace 1995; Ludington and Plumlee 2009). Peripheral base metal and 


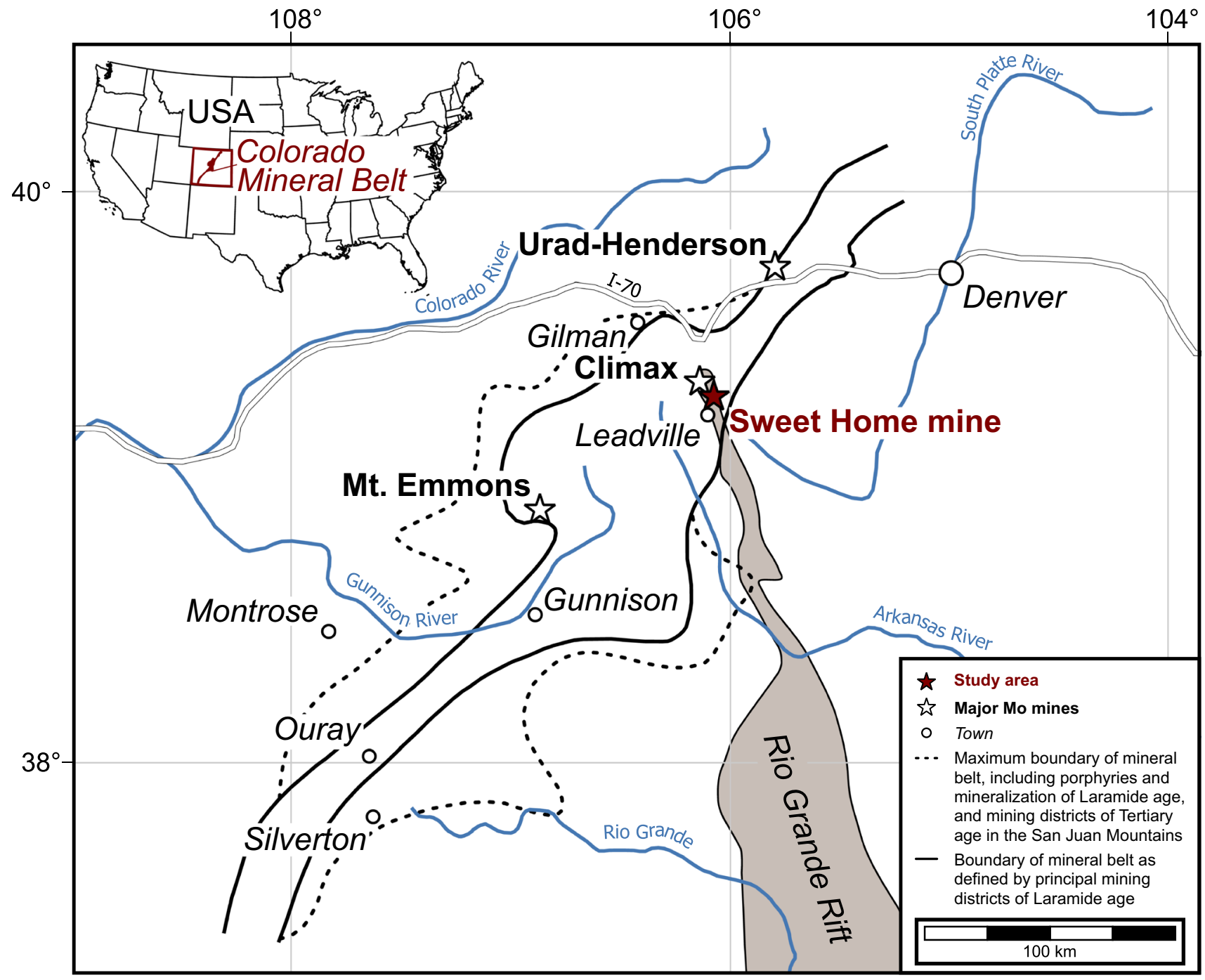

Fig. 1 Location of the Sweet Home mine and major Mo deposits in the Colorado mineral belt. Modified after Tweto and Sims (1963) and White et al. (1981)

rhodochrosite vein mineralization extends from porphyritic rocks into crystalline country rocks and postdates the Mo mineralization (e.g., Bookstrom 1989; Seedorff and Einaudi 2004a). Molybdenum mineralization is assumed to have formed from magmatic fluids that were expelled from the parental magma at temperatures of $710-750{ }^{\circ} \mathrm{C}$ and pressures of 2000-3000 bar, as evidenced by studies of melt inclusions (Lowenstern 1994; Audétat 2015; Mercer et al. 2015). Besides $\mathrm{Mo}$, the melts are enriched in $\mathrm{W}, \mathrm{Pb}, \mathrm{Zn}, \mathrm{Cu}$, $\mathrm{Bi}, \mathrm{Ag}$, and $\mathrm{Mn}$, as well as in the volatile components $\mathrm{H}_{2} \mathrm{O}$, $\mathrm{CO}_{2}$, F, and $\mathrm{Cl}$ (Lowenstern 1994; Audétat 2015; Mercer et al. 2015).

The change of mineralization style from early quartz-molybdenite stockwork veins to later tungstenbearing greisen as well as silver- and base metal-bearing assemblages in ore shells and distal veins above the Mo porphyry ore shells likely resulted from simple cooling of the magmatic-hydrothermal fluid (Wallace et al. 1978; Mutschler et al. 1981; Westra and Keith 1981; White et al. 1981; Stein and Hannah 1985; Stein 1988; Bookstrom 1989; Keith et al. 1993; Wallace 1995; Seedorff and Einaudi 2004a; 2004b; Ludington and Plumlee 2009; Audétat 2010; Mercer et al. 2015). A magmatic origin has also been suggested for sulfur, but it is unclear whether sulfur was derived by mantle degassing (e.g., Wallace 1995; Mercer et al. 2015) or directly from the rhyolitic melts (Stein and Hannah 1985; Lowenstern 1994; Audétat 2015).

In contrast, mixing of magmatic and meteoric fluids was suggested for the formation of Climax-type mineralization, based on fluid inclusion studies (Hall et al. 1974; Bloom 1981; Smith 1983; Rowe 2012). Fluid mixing models were also proposed for the formation of distal vein mineralization related to Climax-type porphyry intrusions (Bartos et al. 2007). Lüders et al. (2009) studied the polymetallic 
vein-type mineralization of the Sweet Home mine (SHM) in Alma, Colorado (Fig. 2). The authors proposed that the mineralization represents the peripheral hydrothermal endmember of a Climax-type porphyry system above an inferred granite cupola (Lüders et al. 2009). Based on fluid inclusions and stable and radiogenic isotope data, they concluded that mineralization at the SHM was formed by mixing of a small proportion of ascending magmatic fluids with larger amounts of externally derived fluids, which interacted intensively with the country rocks (Lüders et al. 2009).

The vein-type mineralization at the Detroit City portal (DCP) of the SHM studied here is located approximately $60 \mathrm{~m}$ above the uppermost SHM workings that were accessible via the Sweet Home portal. The DCP is thus the vertical extension of the SHM (Fig. 3). The SHM was formerly operated as the most productive part of a Ag-base metal vein swarm in the Alma mining district, which extends to the NE through the Red Amphitheater and into Mt. Bross, and to the SW across the Buckskin Creek (ESM Fig. 2). Some features of polymetallic vein-type mineralization at the SHM are similar to those of peripheral veins at the Climax Mo deposit, which is located $\sim 8 \mathrm{~km}$ to the $\mathrm{NW}$, and of the far distal Urad-Henderson Mo deposit (Fig. 1). The similarities include (i) the age of mineralization between 26.0 and 24.8 Ma (Misantoni et al. 1998; Barbá et al. 2005; Romer and Lüders 2006), (ii) the presence of Tertiary porphyry rhyolite dikes and molybdenite-bearing pegmatites (Misantoni et al. 1998), and (iii) the occurrence of a pebble dike ( $7.5 \mathrm{~m}$ thick), which contains rounded clasts of Precambrian rocks in a matrix of quartz, fluorite, and pyrite (Bookstrom 1989). Recent observations of geological features at the SHM support a genetic relationship to a Climax-type Mo porphyry system. In the past years of mining, several greisen veins were exposed at the DCP, which are commonly reported from ore shells in the apical parts of underlying porphyry stocks of Climax-type Mo deposits (ESM Fig. 1). Recent tunneling at the DCP crosscut a major fault known as the Contact Structure (D. Misantoni, pers. commun.), which separates Precambrian biotite-rich metamorphic rocks (Xb; gneiss, schist) from granitic rocks (Xgn; e.g., granite gneiss, pegmatite, migmatite). Outcrops along this structure expose molybdenum-bearing mineralization in the form of molybdenite-quartz-fluorite-pyrite veins and fault gouge.

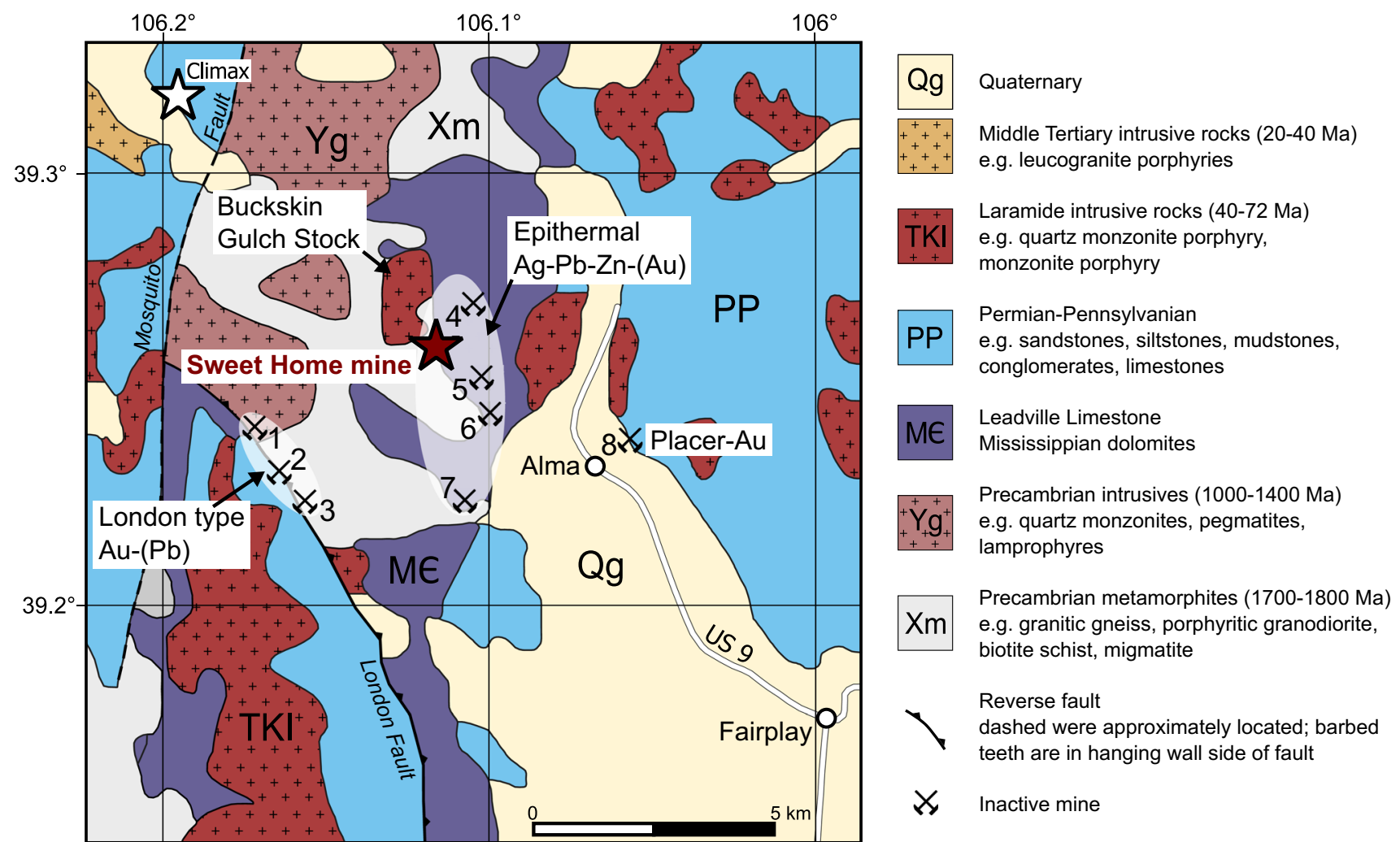

Fig. 2 Geological map of the Mosquito range (Colorado) showing the location of the Sweet Home mine, the Climax Mo deposit, and other historical mining locations. $1=$ North London mine, $2=$ South London mine, 3 =American mine, $4=$ Dolly Varden mine, $5=$ Paris mine,
$6=$ Phillips mine, $7=$ Hock Hocking mine, $8=$ Richards Placer (Misantoni et al. 1998). Strike and dip directions are shown in the detailed geologic maps of the Climax (McCalpin et al. 2012) and Alma quadrangles (Widmann et al. 2004) 
Fig. 3 a Simplified geological map of the Detroit City portal (by courtesy of D. Misantoni). Sample suites marked in yellow contain minerals of the early stage; sample suites in pink contain minerals from the main sulfide stage. Molybdenite occurs at the crosscut of the main vein with the Contact Structure. Sample fields showing more than one number identify different samples from the same locality. $\mathrm{MV}=$ main vein, $\mathrm{WCV}=$ watercourse vein, $\mathrm{BMV}=$ blue mud vein, $\mathrm{TV}=$ tet rahedrite vein, $\mathrm{PV}=$ pyrite vein . b Projection onto cross-section of the Sweet Home mine with the former SHP workings at the bottom and the DCP workings above with horizontal view at the main vein stopes. It is noteworthy that the Contact Structure is only intersected by the DCP workings (by courtesy of S. Bourque)
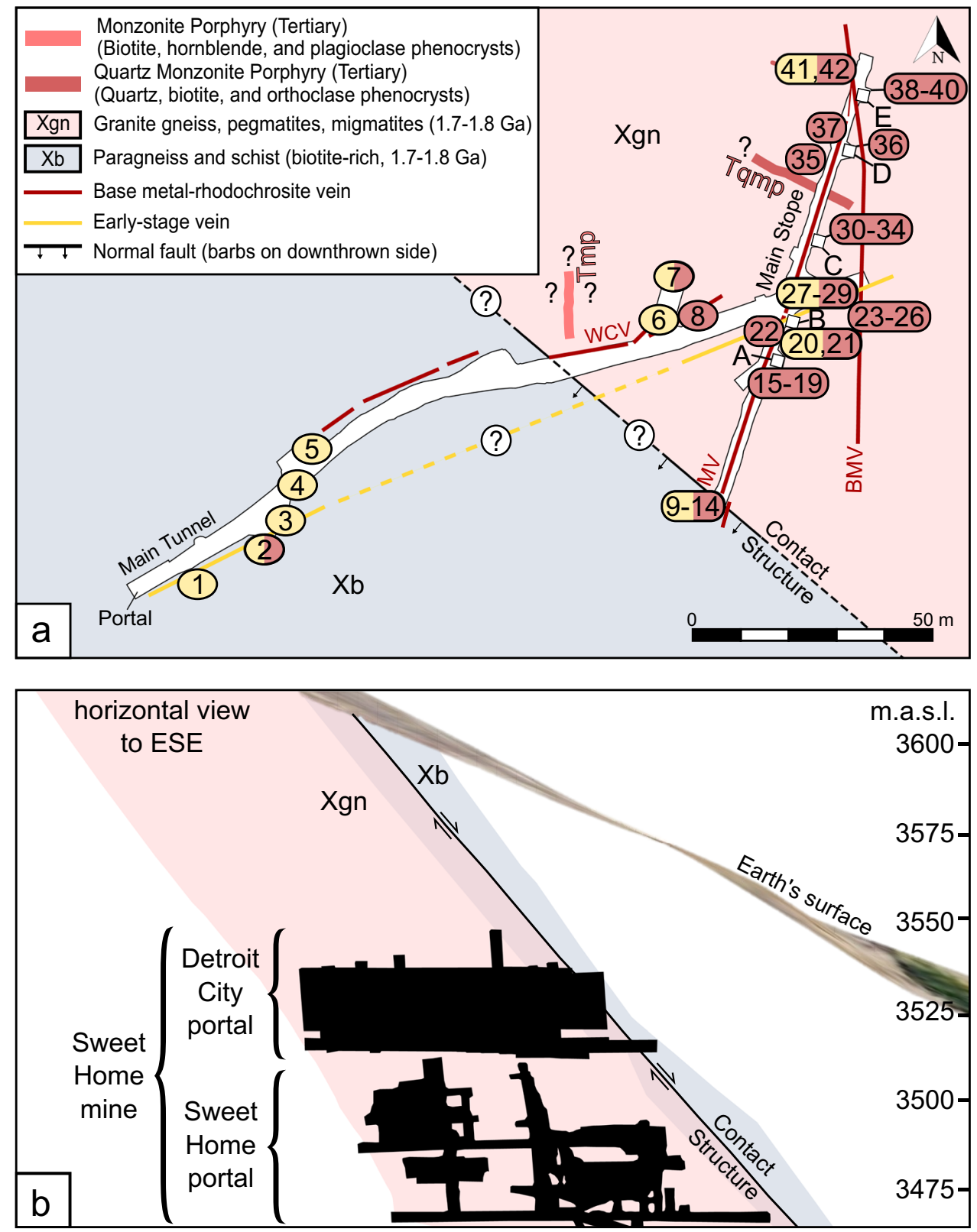

This study aimed to decipher the evolution of the magmatic-hydrothermal system of the SHM in the Alma district and to test a possible relationship of the mineralization to a hypothesized deeper-seated porphyry intrusion, as proposed by Lüders et al. (2009). The minerals from the main sulfide-stage and late-stage mineralization have already been characterized (Lüders et al. 2009); therefore, this study focuses on samples from the Contact Structure and the early-stage (greisen) mineralization. We conducted fluid inclusion microthermometry and laser Raman analyses as well as analyses of fluid inclusion water and gases $\left(\mathrm{CO}_{2}\right.$ and noble gases). In addition, stable $\mathrm{C}, \mathrm{O}$, and $\mathrm{S}$ isotope analyses of carbonates and sulfides were performed.

\section{Geological setting}

\section{Regional geology}

The Colorado Mineral Belt (CMB) extends $\sim 400 \mathrm{~km}$ throughout the present state of Colorado (Fig. 1). It comprises several magmatic intrusions of different age and composition that were emplaced during various tectonic events. The first of these (75-43 Ma) was during the Laramide orogeny and characterized by episodic emplacements of monzonites and granodiorites (Bookstrom 1989). The second event occurred towards the end of Laramide compression (43-37 Ma), where flat slab rollback led to intrusions of quartz monzonites and created pathways 
for fluid migration (Chapin 2012 and references therein). This episode is characterized by $\mathrm{Zn}-\mathrm{Pb}-\mathrm{Ag}-\mathrm{Au}$ sulfide replacement ores at Leadville (Figs. 1, and 2) and by Gilman and Sherman-type $\mathrm{Ag}-\mathrm{Pb}-\mathrm{Zn}-\mathrm{Ba}$ ores in karst zones in Leadville limestones (Behre 1953; Johansing et al. 1990; Thompson and Arehart 1990). After a short period of tectonic inactivity, the Rio Grande Rift system started to develop at ca. 33 Ma (Fig. 1), which was accompanied by the third period of intrusive magmatism (until $25 \mathrm{Ma}$ ), involving both highly evolved silicarich magmas and minor mafic alkaline magmas (Bookstrom 1981, 1989; Bookstrom et al. 1988; Shannon et al. 2004; Ludington and Plumlee 2009). The reactivation of older fault zones and structural lineaments facilitated the ascent of these bimodal magmas and the migration of fluids, enabling the formation of Climax-type Mo porphyry deposits (Lipman and Mehnert 1975; Westra and Keith 1981; White et al. 1981; Bookstrom et al. 1988; Bookstrom 1989; Geissman et al. 1992; Carten et al. 1993; Keith et al. 1993; Wallace and Bookstrom 1993; Russell and Snelson 1994; Shannon et al. 2004; Markey et al. 2007; Ludington and Plumlee 2009; Audétat 2010; Audétat et al. 2011; Mercer et al. 2015) and peripheral $\mathrm{Au} \pm \mathrm{Ag} \pm \mathrm{Mo} \pm$ base metal lodes (Bookstrom 1989; Wallace and Bookstrom 1993; Misantoni et al. 1998; Barbá et al. 2005; Romer and Lüders 2006). The upper parts of the porphyry Mo orebodies exhibit phyllic alteration assemblages of quartz-pyrite-sericite accompanied by greisen quartz-pyrite-topaz-huebnerite-bearing veinlets (e.g., White et al. 1981; Bookstrom 1989). Late peripheral veins contain $\mathrm{Ag}-\mathrm{Pb}-\mathrm{Zn}$-polymetallic sulfides in a gangue of quartz, fluorite, rhodochrosite, calcite, and/or barite (Bookstrom 1989). In both the Climax and UradHenderson areas, Precambrian molybdenum- and tungsten-rich pegmatites, granites, and schists occur (Tweto 1960; Theobald et al. 1983; Wallace 1995), which may be possible metal sources for younger ore mineralization.

\section{Local geology}

Detailed geological descriptions of the Alma district and the Sweet Home mine (SHM) are provided by Misantoni et al. (1998), Widmann et al. (2004), and Bartos et al. (2007) and are briefly summarized here. Geological features, mineralization types, and mining locations are shown in Fig. 2. The Alma mining district hosts different types of ore deposits of former economic interest: (i) Au-bearing polymetallic veins in the London sub-district; (ii) placer gold in glacial, colluvial, and alluvial gravels; and (iii) Ag-bearing polymetallic veins that were mined at the SHM (Misantoni et al. 1998). The SHM was the most productive silver mine among several ones located along a NE-SW to E-W-trending swarm of veins with
$\mathrm{Pb}-\mathrm{Zn}-\mathrm{Cu}-\mathrm{Ag}-\mathrm{W}$ mineralization (ESM Fig. 2). Besides the aforementioned mineralization types, the Alma mining district also hosts minor molybdenum-bearing quartz $( \pm$ fluorite \pm pyrite $)$ veins. Bookstrom et al. (1987; 1988) related the latter to the last pulse of hydrothermal fluids from the underlying Alma Batholith at ca. $26 \mathrm{Ma}$, which may have occurred coevally with the final stage of ore deposition at Climax.

Five main veins are recognized at the SHM, namely, the Main, the Tetrahedrite, the Watercourse, the Blaine, and the Blue Mud veins (Misantoni et al. 1998). The locations of these veins in the Detroit City portal are shown in Fig. 3a, along with recently exposed Pyrite veins (D. Misantoni, pers. commun.). The vertical extension of the mine workings is shown in Fig. 3b. The veins are hosted by Precambrian biotite schist (Fig. 4a), granitic gneisses, and granodiorite. These Precambrian units were intruded by Tertiary quartz-monzonite and monzonite porphyries and molybdenite-bearing quartz-orthoclase pegmatites of possibly Tertiary age (Misantoni et al. 1998).

The rock units were altered and mineralized during multiple events of fluid migration. Propylitic (epidote-chlorite-hematite-pyrite) alteration is ubiquitous, although not directly related to vein mineralization at the SHM. Local potassic alteration of gneisses occurs in the form of plagioclase replacement by K-feldspar, and replacement of coarse metamorphic biotite by fine biotite flakes in the central part of the tetrahedrite vein from the former SHM workings (Bartos et al. 2007). There are rare showings of 1-2-cmwide pinkish K-feldspar veinlets in the same area, which are intersected by base metal sulfide-rhodochrosite veins (Barbá et al. 2005). Phyllic (quartz-pyrite-sericite) and greisen alteration of the host rock are related to emplacement of early-stage greisen veins, pyrite \pm huebnerite \pm sphalerite veins with quartz and fluorite gangue, and muscovite/ sericite or quartz-pyrite-sericite veins (Misantoni et al. 1998; Bartos et al. 2007; Figs. 4b, and 5). Whereas fluorite of the early stage shows strong zonation under hot cathode cathodoluminescence (CL), milky and euhedral quartz do not show CL colors (Fig. 4c). This early-stage vein mineralization locally also contains black sphalerite and huebnerite, the latter yielding a U-Pb age of $25.7 \pm 0.3 \mathrm{Ma}$ (Romer and Lüders 2006). The early-stage mineralization also locally contains isolated, thin, quartz-pyrite-molybdenite veins (Fig. 4d, e) and molybdenite coatings on fractures, which exclusively occur at the crosscut of the main vein with the Contact Structure (Figs. 3a, 4a). The phyllic and greisen alteration was rarely observed in the former SHM workings, but is abundant in the DCP (Fig. 4b). This is due to the orientation of the Contact Structure, which intersects just a small part of the Sweet Home portal (SHP) but larger parts of the DCP workings (Fig. 3b).

Tectonic movements along N-S and NE-trending faults enabled the opening of void spaces and the migration of ore fluids, 
Fig. 4 a Underground outcrop showing the crosscut of the main vein (MV) and the Contact Structure. The offset of the Precambrian rocks $(\mathrm{Xb})$ is indicated by the displaced (white rhyolite) sills. b Sample from a pyrite vein showing greisen assemblages: pyrite, quartz, fluorite, and sericite (sample 6, see Fig. 3 a for location). c CL image showing fluorite in blue CL colors and strong zonation. Note that fluid inclusions are hosted within the zonation layers and do not crosscut grain boundaries. Muscovite (Ms) and quartz (Qtz) are present but do not show CL colors. d Sample 14: Molybdenite vein in a greisen assemblage of pyrite, quartz, and fluorite hosted by altered granite gneiss from the Contact Structure area. The yellow box refers to enlargement in Fig. 4 d. e Photomicrograph showing molybdenite aggregates (Mo) replacing pyrite and quartz (Qtz) crystals (sample 14). f White porphyry sample from the Contact Structure area
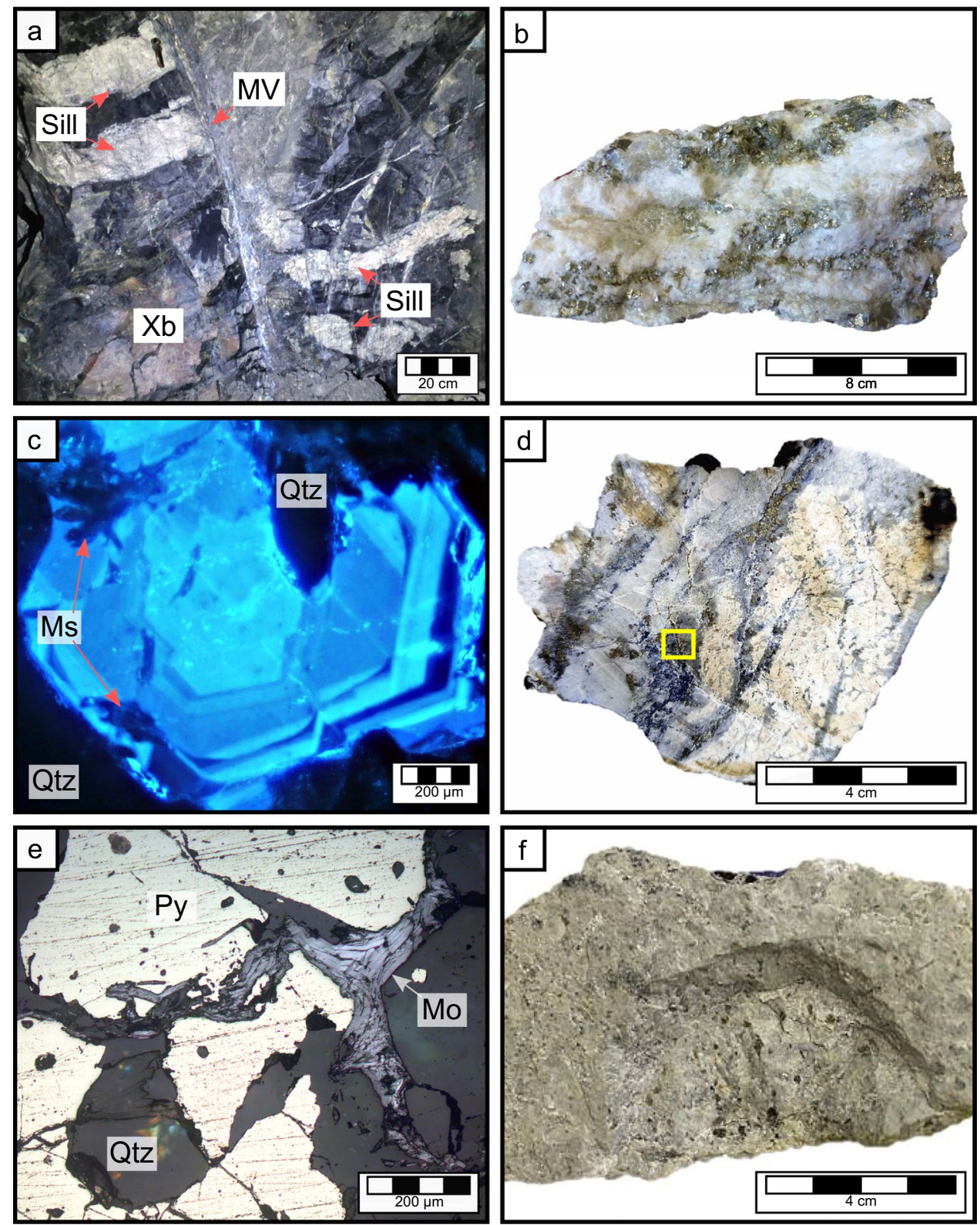

resulting in precipitation of base metal sulfides and gemmy rhodochrosite during the main sulfide stage. Subsequently, rhodochrosite and fluorite precipitated in the late stage, the latter predominantly along NE-trending veins (Misantoni et al. 1998; Fig. 5). The main sulfide stage is characterized by galena, chalcopyrite, sphalerite, bornite, and sulfosalts (tetrahedrite/tennantite) with quartz, gemmy, and murky rhodochrosite and minor purple fluorite as gangue minerals (Fig. 5). The latestage mineralization is made up of pinkish rhodochrosite, purple fluorite, calcite, barite, and apatite (Fig. 5). Late-stage apatite yielded a U-Pb age of $24.8 \pm 0.5 \mathrm{Ma}$ (Romer and Lüders 2006). Some of the main sulfide-stage and late-stage veins are superimposed on the early-stage veins.

The emplacement of intrusive rocks in the area of the SHM was structurally controlled (Misantoni et al. 1998).
Three major structural trends are present: (i) an early NW-SE to E-W fault and fracture trend that is parallel to foliation and banding in the Precambrian gneiss, (ii) a NE-SW fault trend that contains the majority of the productive veins, and (iii) a late, $\mathrm{N}$-S-trending fault and fracture zone. All three trends contain porphyry intrusions that are hydrothermally altered and mineralized. Several other tectonic features were observed since the opening of the DCP in 2017. The most important one is a NW-SE-trending and SW-dipping fault, known as the Contact Structure (D. Misantoni, pers. commun.). This fault is likely Precambrian in age, and it forms the contact between Precambrian gneiss to the NE and biotite schist to the SW (Fig. 3a, b). The Contact Structure in the DCP was intruded by a white porphyry dike with similar mineralogical features (e.g., alteration 
Fig. 5 Simplified paragenetic scheme of the mineralization at the Sweet Home mine

\begin{tabular}{|c|c|c|c|}
\hline & $\begin{array}{l}\text { Early stage: Greisen veins, } \\
\text { greisen / phyllic alteration }\end{array}$ & $\begin{array}{l}\text { Main sulfide } \\
\text { stage }\end{array}$ & Late stage \\
\hline \multicolumn{4}{|l|}{ Gangue minerals } \\
\hline $\begin{array}{l}\text { Milky quartz } \\
\text { Euhedral quartz } \\
\text { Fluorite } \\
\text { Muscovite } \\
\text { Rhodochrosite } \\
\text { Calcite } \\
\text { Apatite } \\
\text { Barite }\end{array}$ & orange, green, transparent & gurple & $\begin{array}{l}\text { purple } \\
\text { pink }\end{array}$ \\
\hline \multicolumn{4}{|l|}{ Ore minerals } \\
\hline $\begin{array}{l}\text { Huebnerite } \\
\text { Pyrite } \\
\text { Molybdenite } \\
\text { Sphalerite } \\
\text { Tetrahedrite/Tennantite } \\
\text { Galena } \\
\text { Chalcopyrite } \\
\text { Bornite }\end{array}$ & 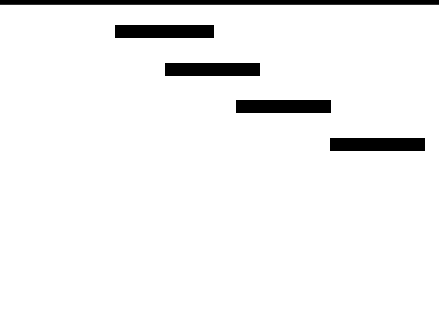 & & \\
\hline
\end{tabular}

style, pyramidal quartz phenocrysts, Fig. 4f) as the porphyry stocks found at Climax. Most of the molybdenite-bearing samples found at the DCP so far were retrieved from outcrops along the Contact Structure (Fig. 3a).

\section{Samples and analytical methods}

\section{Sampling and petrography}

The samples studied here originate from the DCP (Fig. 3a, b) and were collected to represent early-stage mineralization consisting mostly of milky quartz, fluorite, muscovite, and pyrite, locally also huebnerite and/or sphalerite. Some earlystage assemblages contain molybdenite vein fillings, which have not been reported from the former Sweet Home workings at all. A detailed description of the samples is shown in Table 1. The ESM Table 1 provides an overview of the methods used, which are briefly described below.

Doubly-polished thick sections of ore and gangue minerals were prepared at the Institute of Geosciences, University of Potsdam (Germany), for transmitted and reflected light microscopy, fluid inclusion (FI) microthermometry, and laser Raman spectroscopy. Following the recommendation by Lüders and Ziemann (1999), the thickness of pyrite sections for microscopic observations in near infrafred (IR) light was $90 \mu \mathrm{m}$. All other thick sections have a thickness of ca. $180 \mu \mathrm{m}$. Moreover, representative samples were selected for CL petrography. The hot-cathode optical CL system was operated at $14 \mathrm{keV}$ and $0.10-0.20 \mathrm{~mA}$. Exposure times were varied to capture zonation and differences in luminescence.

\section{Microthermometry}

Fluid inclusions in transparent minerals (quartz, fluorite, sphalerite, huebnerite) were measured by conventional microthermometry using a FLUID INC-adapted U.S.G.S. gas-flow heating/freezing system mounted on an Olympus BX50 microscope with a long-distance $\times 40$ objective with coverslip correction. Fluid inclusions in pyrite were measured using a Linkam THMS 600 heating/freezing system on an Olympus BHSM-IR microscope with a $50 \times$ IR objective and a QCam infrared InGaAs camera, which allows observation in the wavelength range between $\lambda=800$ and $1800 \mathrm{~nm}$ at low IR light intensity (Lüders 2017). Some samples of huebnerite and sphalerite, which showed highly variable transmittance, were studied either in transmitted light or in near IR light. Both approaches using a Linkam and a U.S.G.S. system are operated at the German Research Centre for Geosciences (Potsdam, Germany).

The Linkam and U.S.G.S. heating-freezing stages were calibrated with Synflinc synthetic inclusions (Sterner and Bodnar 1984). The measurement precision is $\pm 0.1{ }^{\circ} \mathrm{C}$ for ice melting temperatures $\left(T_{\mathrm{m}}\right)$ and $\pm 1{ }^{\circ} \mathrm{C}$ for homogenization temperatures. Salinity in equivalent weight percent $\mathrm{NaCl}$ (wt\% equiv. $\mathrm{NaCl}$ ) was calculated from low-temperature phase changes using the HokieFlincs_ $\mathrm{H}_{2} \mathrm{O}-\mathrm{NaCl}$ spreadsheet (Bodnar 1993; Steele-MacInnis et al. 2012). The salinity of 
Table 1 Sample origin and description

\begin{tabular}{|c|c|c|c|}
\hline $\begin{array}{l}\text { Sample } \\
\text { number }\end{array}$ & $\begin{array}{l}\text { Approximate ele- } \\
\text { vation (m.a.s.l. })^{2}\end{array}$ & Stage $^{3}$ & Assemblage $^{3,4}$ \\
\hline 1 & 3515 & Early stage & Qtz-Ms-Py vein with orange and green $\mathrm{Fl}$ in pores \\
\hline 2 & 3515 & Early stage, main sulfide stage & Qtz-Py-Hub-Fl overgrown by euhedral Qtz and base metal sulfides \\
\hline 3 & 3515 & Early stage, main sulfide stage & Disseminated Py in altered $\mathrm{Xb}$, overgrown by euhedral early-stage $\mathrm{Sp}$ and violet $\mathrm{Fl}$ \\
\hline 4 & 3515 & Early stage & Qtz-Py-Ms-orange $\mathrm{Fl}$ with more orange $\mathrm{Fl}$ and euhedral $\mathrm{Sp}$ in pores \\
\hline 5 & 3515 & Early stage & Qtz-Fl-Ms-Py vein \\
\hline 6 & 3515 & Early stage & Qtz-Ms-Py-Hub vein \\
\hline 7 & 3515 & Early stage, main sulfide stage & Qtz-Py vein replaced by base metal sulfides \\
\hline 8 & 3515 & Early stage, late stage & Qtz-Py-Hub vein with minor pink Rds and late violet-Fl \\
\hline 9 & 3515 & Early stage, main sulfide stage & Py in a massive sulfide matrix (Tet/Ttn, Gn, Sp) with minor Qtz and murky Rds \\
\hline 10 & 3530 & Early stage, main sulfide stage & Py in a massive sulfide matrix $(\mathrm{Ccp}, \mathrm{Sp})$ \\
\hline 11 & 3525 & Early stage, main sulfide stage & Qtz-Py vein with minor Hub, Sp and main sulfide-stage base metals \\
\hline 12 & 3515 & Early stage & Disseminated Py in altered Xgn with Mo coating \\
\hline 13 & 3515 & Early stage & Disseminated Py in altered Xgn with Mo coating \\
\hline 14 & 3525 & Early stage & Disseminated Py in altered Xgn cut by Qtz-Fl-Py-Mo vein \\
\hline 15 & 3520 & Early stage, main sulfide stage & $\begin{array}{l}\text { Disseminated Qtz and Py in altered Xgn bordering a massive base metal sulfide-murky Rds } \\
\text { vein }\end{array}$ \\
\hline 16 & 3525 & Main sulfide stage, late stage & Massive base metal sulfide vein together with late violet fluorite \\
\hline 17 & 3515 & Main sulfide stage, late stage & Massive base metal sulfide together with late violet fluorite \\
\hline 18 & 3515 & Main sulfide stage & Massive base metal sulfide \\
\hline 19 & 3515 & Main sulfide stage, late stage & Pink Rds crystals growing on base metal sulfides \\
\hline 20 & 3520 & Early stage, main sulfide stage & $\begin{array}{l}\text { Disseminated Qtz and Py in altered Xgn bordering a massive base metal sulfide-murky Rds } \\
\text { vein }\end{array}$ \\
\hline 21 & 3525 & Early stage, main sulfide stage & Py in a massive sulfide matrix with minor Qtz and murky Rds \\
\hline 22 & 3515 & Main sulfide stage & Base metal sulfides in a gangue of murky Rds and differentially colored Fl \\
\hline 23 & 3515 & Late stage & Pink Rds crystals \\
\hline 24 & 3515 & Late stage & Pink Rds together with euhedral Qtz, Ap, and clay \\
\hline 25 & 3515 & Late stage & Pink Rds and minor violet Fl crystals \\
\hline 26 & 3515 & Late stage & Pink Rds and minor Ap crystals \\
\hline 27 & 3515 & Early stage & Qtz-Py-Hub vein \\
\hline 28 & 3515 & Early stage & Qtz-Ms-Py-Sp-Hub overgrown by euhedral Qz, base metal sulfides, and Rds \\
\hline 29 & 3515 & Early stage & Qtz-Py-Hub-Sp growing in open space \\
\hline 30 & 3515 & Late stage & Pink Rds and violet Fl crystals on Tet/Ttn \\
\hline 31 & 3515 & Late stage & Pink Rds crystals \\
\hline 32 & 3515 & Early stage, main sulfide stage & Disseminated Py in altered Xgn bordering a massive base metal sulfide-murky Rds vein \\
\hline 33 & 3515 & Main sulfide stage, late stage & Euhedral Qtz and pink Rds growing on massive base metal sulfides \\
\hline 34 & 3515 & Late stage & Rds crystals \\
\hline 35 & 3515 & Early stage, main sulfide stage & Remnants of early-stage Py in a vein of Qtz-base metal sulfide-violet Fl \\
\hline 36 & 3515 & Late stage & Pink Rds and violet Fl crystals \\
\hline 37 & 3515 & Main sulfide stage, late stage & Altered Xgn bordered by Qtz-base metal sulfides-pink Rds together with late violet $\mathrm{Fl}$ and Ap \\
\hline 38 & 3515 & Main sulfide stage, late stage & Pink Rds crystals growing on Tet/Ttn \\
\hline 39 & 3515 & Main sulfide stage, late stage & Pink Rds together with euhedral Qtz, base metals sulfides, and violet Fl \\
\hline 40 & 3515 & Main sulfide stage, late stage & Pink Rds growing on massive base metal sulfides \\
\hline 41 & 3525 & Early stage, main sulfide stage & Py in a massive sulfide matrix with minor Qtz \\
\hline 42 & 3520 & Early stage, main sulfide stage & Coarse-grained massive sulfide-murky Rds sample with remnants of early Qtz-Py-Sp \\
\hline 43 & Dump & Early stage & Qtz-Hub vein \\
\hline
\end{tabular}

${ }^{1}$ Sample locations are shown in Fig. 5a

${ }^{2}$ Vertical extension of the mine workings are shown in Fig. 5b

${ }^{3}$ Relative timing of mineralization stages and mineral assemblages are displayed in Fig. 7

${ }^{4} Q t z$ quartz, $M s$ muscovite, $P y$ pyrite, $H u b$ hubnerite, $F l$ fluorite, $S p$ sphalerite, $R d s$ rhodochrosite, Tet tetrahedrite, Ttn tennantite, Gn galena, $C c p$ chalcopyrite, $M o$ molybdenite, $A p$ apatite, $X b$ Biotite schist, $X g n$ Granite gneiss 
$\mathrm{CO}_{2}$-bearing inclusions was calculated via clathrate melting temperatures using the equations from Darling (1991) and Barton and Chou (1993).

\section{Laser Raman spectroscopy}

The gas contents in vapor-rich inclusions and vapor bubbles of aqueous two-phase fluid inclusions as well as trapped solid phases were analyzed using a Jobin-Yvon LabRam confocal laser Raman microspectrometer paired with an Olympus optical microscope at the German Research Centre for Geosciences (Potsdam, Germany). All measurements were taken with an MPlan $100 \times / 0.90$ objective lens. The excitation radiation was from a $532.6 \mathrm{~nm}$ Nd-YAG laser (100 $\mathrm{mW})$. Silicon $\left(520 \mathrm{~cm}^{-1}\right)$ and diamond $\left(1332 \mathrm{~cm}^{-1}\right)$ were used for internal calibration. Raman spectra were collected in the spectral range between 100 and $1300 \mathrm{~cm}^{-1}$ for gas-rich and aqueous inclusions and between 1200 and $2950 \mathrm{~cm}^{-1}$ for trapped solids. Acquisition times were $2 \times 30 \mathrm{~s}$ for gas-rich and aqueous inclusions and $2 \times 60$ s for solids.

\section{Hydrogen and oxygen isotope analysis of fluid inclusions}

Isotope analysis of fluid inclusion water was made on selected ore and gangue minerals from the early greisen stage, as well as from the main sulfide and late stage, at the Max Planck Institute for Chemistry (Mainz, Germany). Bulk analyses of fluid inclusion hydrogen and oxygen isotope ratios were performed using two different continuous-flow techniques designed for online analysis of mineral samples of up to $2 \mathrm{~g}$ (de Graaf et al. 2020a). One technique couples a mechanical crusher unit to a continuous-flow isotope ratio mass spectrometry (IRMS) instrument (Thermo Scientific Delta V). The crusher unit is maintained at a temperature of $120{ }^{\circ} \mathrm{C}$ to achieve complete evaporation of fluid inclusion water upon sample crushing. The released water vapor is collected in a cryogenic trap that can be heated to generate a water pulse long enough to be analyzed. After leaving the cryogenic trap, the water vapor is guided to a continuousflow pyrolysis furnace (Thermo Scientific TC-EA), which produces $\mathrm{H}_{2}$ and $\mathrm{CO}$ gas as a result of reaction with glassy carbon at $1400{ }^{\circ} \mathrm{C}$. The $\mathrm{H}_{2}$ and $\mathrm{CO}$ are subsequently introduced to the IRMS instrument where a rapid magnet peak jump allows for analysis of both hydrogen and oxygen isotopes from a single water release. Isotope values of fluid inclusion water are reported as $\delta^{2} \mathrm{H}_{\mathrm{w}}$ and $\delta^{18} \mathrm{O}_{\mathrm{w}}$ ratios relative to VSMOW. Samples measured following the analytical protocol are typically reproducible $(1 \sigma)$ within $0.4 \%$ for $\delta^{18} \mathrm{O}_{\mathrm{w}}$ and $2.0 \%$ o for $\delta^{2} \mathrm{H}_{\mathrm{w}}$.

The second technique makes use of a cavity ring-down spectroscopy (CRDS) instrument (Picarro L2140-i) connected to a crusher unit at $120{ }^{\circ} \mathrm{C}$. The $\mathrm{N}_{2}$ carrier gas in the system is continuously moisturized to create a stable water vapor background and eliminate memory effects in the analyzer. Mineral samples are crushed to liberate fluid inclusion water and generate a peak addition to the steady water background. Oxygen and hydrogen isotope values of the fluid inclusion water can be calculated by subtracting the background from the sample peak. Reproducibility of mineral crushes on the CRDS system is within $0.3 \%$ for $\delta^{18} \mathrm{O}_{\mathrm{w}}$ and $1.1 \%$ ofor $\delta^{2} \mathrm{H}_{\mathrm{w}}$. Both the IRMS and CRDS setup produce accurate fluid inclusion isotope data as shown in a comparison experiment for these two techniques reported by de Graaf et al. (2020a).

\section{Carbon and nitrogen isotope analysis of fluid inclusions}

The carbon isotopic composition of carbon dioxide and methane as well as the nitrogen isotopic composition of fluid inclusions hosted in fluorite and quartz was analyzed using a sample crusher connected via a GC-column to an elemental analyzer (EA)-IRMS system at the German Research Centre for Geosciences (Potsdam, Germany). The system uses a continuous flow of He carrier gas (purity 5.0) at a stable rate of $300 \mathrm{ml} / \mathrm{min}$. After crushing of 0.2-0.5 g sample chips, the He-gas mixture passes through a molecular sieve where $\mathrm{N}_{2}, \mathrm{CH}_{4}$ (if present), and $\mathrm{CO}_{2}$ are separated from each other. The gas species enter the oxidation column of the EA, where $\mathrm{CH}_{4}$ (if present) is oxidized to $\mathrm{CO}_{2}$ with simultaneous injection of $\mathrm{O}_{2}$ at $960{ }^{\circ} \mathrm{C}$. After passing the reduction column and water trap, the gas species $\mathrm{N}_{2}, \mathrm{CO}_{2}$ from $\mathrm{CH}_{4}$ oxidation, and original $\mathrm{CO}_{2}$ from inclusions are separated in a second molecular sieve and enter the IRMS via a Conflo III interface. The isotopic ratios of nitrogen and carbon dioxide were measured online and compared to reference gases calibrated against IAEA-N1 for $\mathrm{N}_{2}$ and NBS19 for $\mathrm{CO}_{2}$. Reproducibility of the $\delta^{15} \mathrm{~N}\left(\mathrm{~N}_{2}\right)$ and $\delta^{13} \mathrm{C}\left(\mathrm{CO}_{2}, \mathrm{CH}_{4}\right)$ values of fluid inclusion gases are at or below $1.1 \%$. For details, see Plessen and Lüders (2012).

\section{Carbon and oxygen isotope analysis of rhodochrosite}

Crushed rhodochrosite samples were analyzed for carbon and oxygen isotopes on a Thermo Scientific Delta V Advantage mass spectrometer equipped with a Gasbench II gas preparation unit (Thermo Scientific) at the Department of Earth Sciences, Vrije Universiteit Amsterdam (Netherlands). Around $10 \mu \mathrm{g}$ of sample material was placed in a He-filled 12-ml exetainer vial for sample digestion in concentrated anhydrous $\mathrm{H}_{3} \mathrm{PO}_{4}$ at a temperature of $45{ }^{\circ} \mathrm{C}$. The generated $\mathrm{CO}_{2}-\mathrm{He}$ gas mixture was transported into the Gasbench II in a He carrier flow. In the Gasbench II, water was removed through Nafion tubing, and $\mathrm{CO}_{2}$ was analyzed in 
the mass spectrometer after extraction of residual gases in a GC column. Raw data were calibrated against the calcite Vrije Universiteit Amsterdam-Internal Carbonate Standard (VICS; $1.45 \%$ for $\delta^{13} \mathrm{C}$ and $-5.44 \%$ or $\delta^{18} \mathrm{O}$ ). This introduces no bias since rhodochrosite and calcite have a similar phosphoric acid fractionation factor. The isotope ratios are reported as $\delta^{13} \mathrm{C}_{\mathrm{Rds}}$ and $\delta^{18} \mathrm{O}_{\mathrm{Rds}}$ ratios relative to VPDB. The typical reproducibility $(1 \sigma)$ of routinely analyzed carbonate standards is better than $0.1 \%$ for both $\delta^{13} \mathrm{C}$ and $\delta^{18} \mathrm{O}$.

\section{Noble gas analysis of fluid inclusions}

Noble gas analyses were performed on 0.2 to $1.0 \mathrm{~g}$ of handpicked separates of ore and gangue minerals from the early and main sulfide stages at the German Research Centre for Geosciences (Potsdam, Germany). The samples were loaded into an ultrahigh-vacuum spindle crusher, which was pumped at room temperature for $24 \mathrm{~h}$ to remove atmospheric gases adsorbed on grain surfaces. For gas extraction, the samples were crushed under vacuum, and the gases released were admitted to the preparation line. Water was frozen in a dry ice-cooled trap and other chemically active species were removed in $\mathrm{Ti}$ sponge and $\mathrm{ZrAl}$ getters. The noble gases were then separated from each other in a cryogenic adsorber, and noble gas concentrations and isotopic compositions were determined in a VG5400 noble gas mass spectrometer according to procedures described by Niedermann et al. (1997). Total analytical blanks (determined prior to each crushing extraction, in $\mathrm{cm}^{3} \mathrm{STP}$ ) were $(1-4) \times 10^{-12}$ for ${ }^{4} \mathrm{He},(0.5-2.3) \times 10^{-12}$ for ${ }^{20} \mathrm{Ne},(4-14) \times 10^{-10}$ for ${ }^{40} \mathrm{Ar}$, and $(3-15) \times 10^{-14}$ for both ${ }^{84} \mathrm{Kr}$ and ${ }^{132} \mathrm{Xe}$, with atmospheric isotopic compositions.

\section{Reliability of fluid inclusion bulk analysis}

Bulk analysis of fluid inclusions extracted from minerals by crushing or heating inevitably provides data from all fluid inclusion populations (i.e., primary and secondary fluid inclusions) present in a sample. This is a major point of criticism against the reliability of bulk crush-leach or isotope analysis (see Chi et al. 2021 and references therein). However, the validity of bulk analysis can be increased considerably by carefully evaluating the fluid inclusion inventory and selecting samples that contain only one dominant fluid inclusion population. Plessen and Lüders (2012) tested the validity of fluid inclusion bulk analysis in a study using an online technique for carbon isotope analysis of $\mathrm{CO}_{2}$ in fluid inclusions. The authors showed that variations in $\delta^{13} \mathrm{C}_{\mathrm{CO} 2}$ values of quartz-hosted gas-rich fluid inclusion assemblages in previously studied quartz chips from the Ashanti gold mine (samples GH-172 and GH-151) gave excellent reproducibility in the range of 0.5 and $0.4 \%$, respectively. The same holds true for $\delta^{13} \mathrm{C}$ values of $\mathrm{CO}_{2}$ and $\mathrm{CH}_{4}$ and $\delta^{15} \mathrm{~N}$ values of gas-rich inclusions hosted in different minerals in other case studies (e.g., Lüders et al. 2012; Plessen and Lüders 2012; Lüders and Plessen 2015). The results of these studies show that the influence of different fluid inclusion populations can be minimized by careful sample selection. Similarly, excellent reproducibility was found for online analysis of $\delta^{2} \mathrm{H}$ and $\delta^{18} \mathrm{O}$ of fluid inclusion water in various minerals from vein-type ore and fluorite from the Harz Mountains in Central Germany (de Graaf et al. 2020b). For this study, only samples that dominantly host one fluid inclusion population were chosen for bulk isotope analyses; thus, we are confident that the results represent a single fluid event.

\section{Sulfur isotope analysis}

Sulfides and sulfosalts from the early greisen and main sulfide stages were measured via EA-IRMS (elemental analyzer-isotope ratio mass spectrometer) using a FlashEA Isolink CN interfaced to a ThermoScientific Delta V Advantage mass spectrometer at the Institute for Geology and Paleontology, University of Münster (Germany). Depending on the specific mineral, between 150 and $450 \mu \mathrm{g}$ of hand-picked separates were homogeneously mixed with $200-600 \mu \mathrm{g}$ of vanadium pentoxide and weighed in a tin capsule. Reference materials for sulfur isotope measurements were NBS-127, IAEA-S-1, IAEA-S-2, and IAEA-S-3, and an in-house $\mathrm{Ag}_{2} \mathrm{~S}$ standard. External reproducibility as determined through replicate analyses of reference materials was better than $\pm 0.3 \%$ o $(1 \sigma)$.

\section{Results}

\section{Fluid inclusion petrography}

The classification of fluid inclusions (FIs) as primary, pseudosecondary, and secondary and the definition of fluid inclusion assemblages (FIA; coevally trapped fluid inclusions along features such as crystal planes, growth zones, or healed microfractures) followed the criteria suggested by Roedder (1984) and Goldstein and Reynolds (1994).

We identified three types of fluid inclusions hosted in gangue and ore minerals of the early-stage mineralization: type $1-$ vapor-rich aqueous carbonic, three-phase FIs in milky quartz and fluorite; type 2-vapor-rich, two-phase FIs in milky quartz and fluorite; and type 3-aqueous, two-phase FIs in milky quartz, fluorite, pyrite, huebnerite, and sphalerite (Table 2).

At room temperature, aqueous carbonic type 1 FIs contain a vapor bubble, liquid $\mathrm{CO}_{2}$, and minor aqueous liquid (Fig. 6a, b). Coevally trapped FIAs of type 1, 2, and 3 inclusions were found in early-stage quartz and fluorite (Fig. 6a, b). Some type 2 and 3 FIs hosted in fluorite near muscovite (coarse and/or 


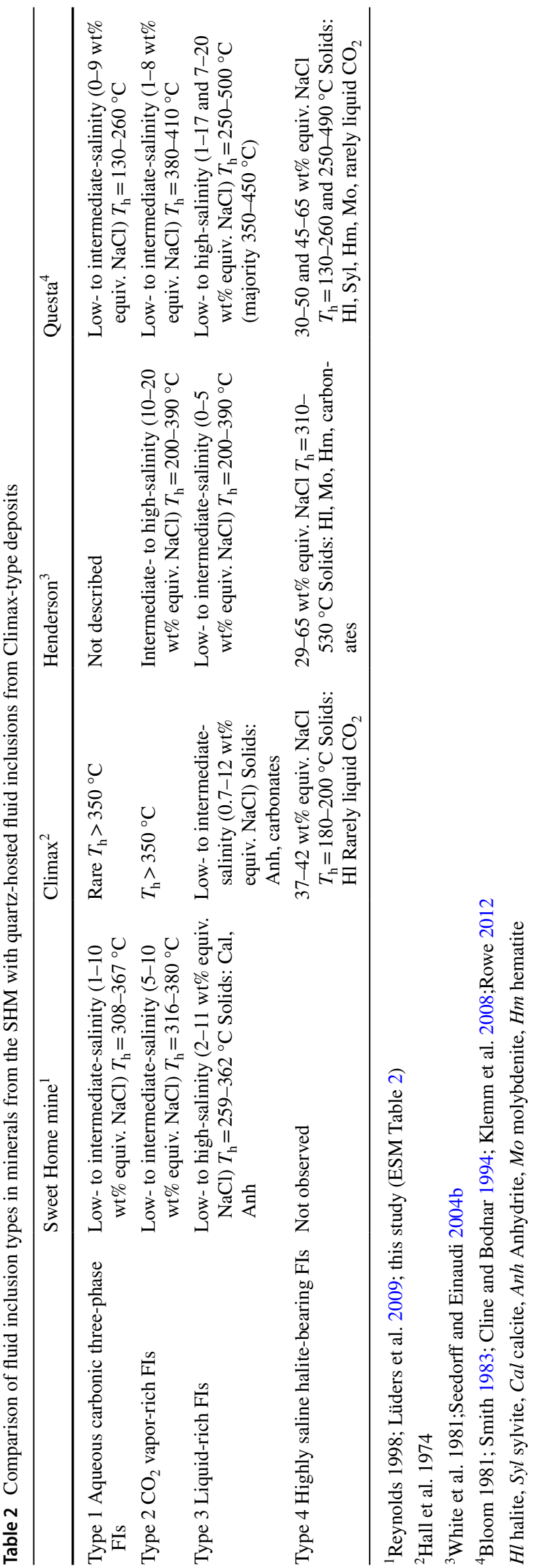

sericite) contain solid inclusions of calcite (Fig. 6c) or anhydrite (Fig. 6d). Additionally, fluorite hosts isolated primary type 1 and 3 FIs, which locally show negative crystal shapes (Fig. 6a). Quartz locally shows growth zones that are decorated with primary type 3 FIs (Fig. 6e).

Aqueous, two-phase type 3 FIs are most common in early-stage quartz, fluorite, and in the ore minerals sphalerite, huebnerite (Fig. 6f), and pyrite (Fig. 6g), where the inclusions occur in clusters or are arranged along trails.

Due to the great abundance of FIs in some inclusion trails and clusters, a classification of primary, pseudosecondary, or secondary is uncertain or even impossible. However, these trails and clusters are always found within growth zones, which are visible in fluorite under CL (Fig. 4c), or in individual crystals, where they do not cross grain boundaries. Therefore, the investigated FIs may be pseudosecondary rather than primary, but they are unlikely to be secondary and thus are valid for interpretation of mineralization conditions.

Generally, type 1 and 2 FIs can mostly be classified as primary, whereas type 3 FIs may be either of primary or of secondary origin. However, secondary type 3 FIs in early-stage minerals are rare and commonly are arranged along trails crosscutting fluorite. The liquid-vapor ratios of secondary inclusions are considerably higher than those in primary and pseudosecondary type 3 FIs (Fig. 6h); they are not included in Fig. 7.

\section{Fluid inclusion microthermometry}

Microthermometric measurements of FIs were performed on early-stage quartz, fluorite, huebnerite, pyrite, and sphalerite samples from six different locations in the DCP $(1,5,8,14$, 27, and 29 in Fig. 3a). The results are shown in Fig. 7 and ESM Table 2. In general, type 1 FIs (e.g., Fig. 6a) show homogenization of $\mathrm{CO}_{2}$ followed by total homogenization to the liquid phase or to the vapor phase. In contrast, type 2 FIs always show homogenization to vapor. It was commonly impossible to measure the final homogenization temperatures $\left(T_{\mathrm{h}}\right)$ in vaporrich type 1 and 2 FIs due to decrepitation. Type 3 FIs always showed vapor to liquid homogenization during heating runs. A first melting temperature $\left(T_{\mathrm{e}}\right)$ was only observed in a few FIs hosted in fluorite and sphalerite. The $T_{\mathrm{e}}$ values for fluoritehosted inclusions are between -28 and $-26^{\circ} \mathrm{C}$, lower than those measured in FIs hosted in sphalerite $\left(-25.5\right.$ to $\left.-17.5^{\circ} \mathrm{C}\right)$. Melting of clathrate was observed in type 1 FIs, whereas in type 2 and in most of type 3 FIs, melting of either ice or clathrate was observed. Both ice and clathrate melting temperatures could be observed only in some type 3 FIs hosted in sphalerite.

Fluorite associated with molybdenite in fracture-fill mineralization (sample 14, Fig. 7) dominantly contains $\mathrm{CO}_{2}$-bearing type 3 FIs as indicated by frequently observed melting of clathrate and the presence of $\mathrm{CO}_{2}$ peaks in Raman spectra. The salinity varies between 5.8 and $10.4 \mathrm{wt} \%$ equiv. $\mathrm{NaCl}$. Values of $T_{\mathrm{h}}$ for primary FIs hosted in fluorite that is 
Fig. 6 Photomicrographs of FIs hosted in early-stage greisen mineralization. a Trails of carbonic three-phase (type 1), vapor-rich (type 2), and aqueous, liquid-rich (type 3) FIs in fluorite showing negative crystal shape (sample 1). Focused type 1 FIs show different carbonic homogenization behavior as the top right one homogenizes to the liquid phase at $30.8{ }^{\circ} \mathrm{C}$ and the bottom left one to the vapor phase at $31.0^{\circ} \mathrm{C}$. b A cluster of carbonic three-phase (type 1), vapor-rich (type 2), and lowcarbonic, aqueous, liquid-rich (type 3) FIs in milky quartz (sample 5). c Trail of vaporrich (type 2) and low-carbonic, aqueous, liquid-rich (type 3 ) FIs in fluorite. The focused FI shows an inherited calcite crystal (sample 5). d Lowcarbonic, aqueous, liquid-rich (type 3) FIs in fluorite showing an inherited anhydrite crystal (sample 14). e Quartz showing growth zone boundaries and focused low-carbonic, aqueous, liquid-rich (type 3) FIs (sample 11). f Aqueous, liquid-rich type 3 FIs in huebnerite (sample 8). g Infrared photomicrograph of a cluster of irregularly shaped aqueous, liquid-rich type 3 FIs in pyrite (sample 27). $\mathbf{h}$ Aqueous, liquid-rich type 3 FIs in fluorite showing high liquid-tovapor ratio (sample 16)
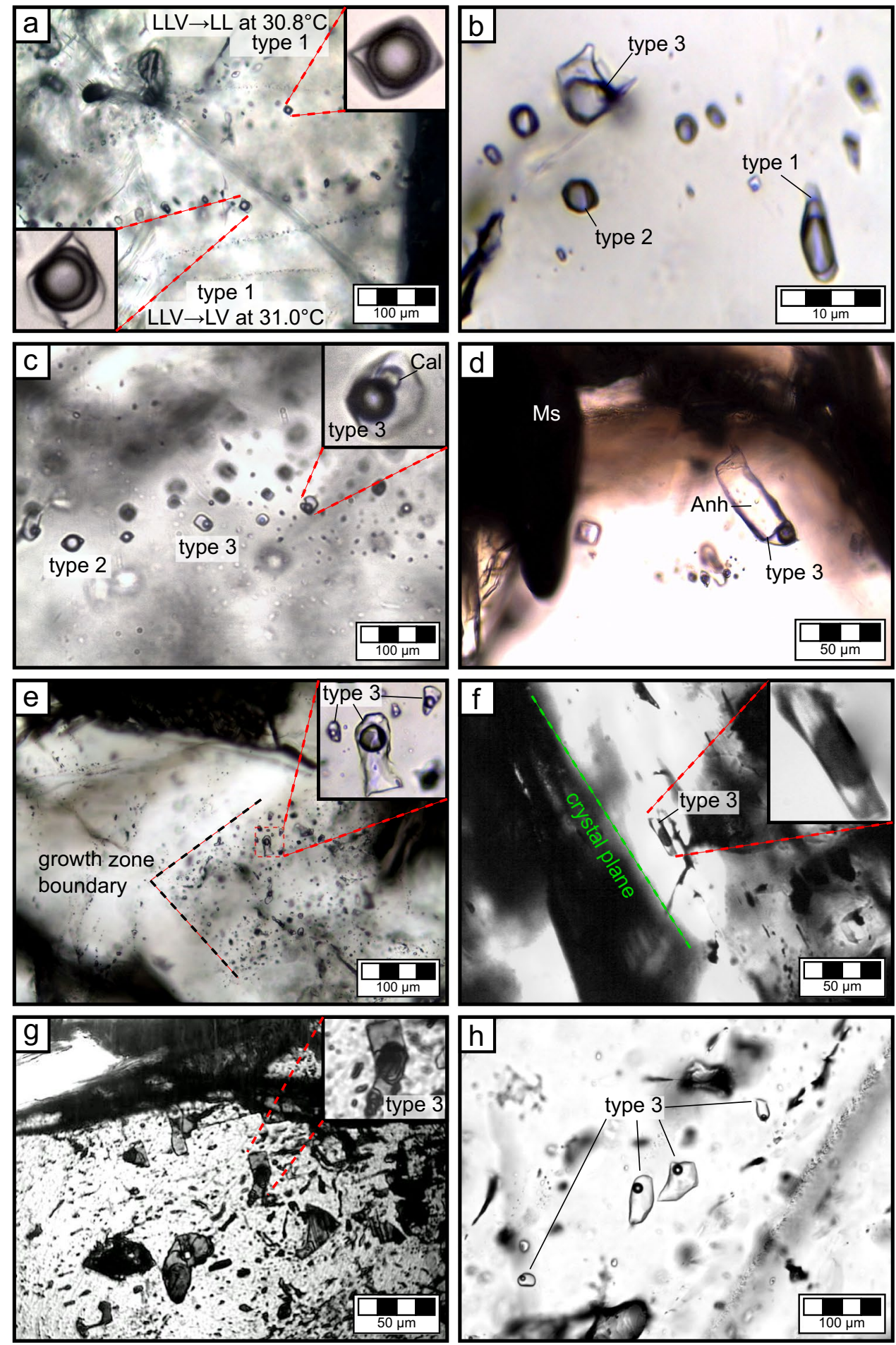

directly intergrown with molybdenite range between 320 and $337^{\circ} \mathrm{C}$, whereas primary FIs in fluorite from the outer rim of the sample (i.e., distal from the molybdenite) show lower $T_{\mathrm{h}}$ values between 271 and $299^{\circ} \mathrm{C}$ (Fig. 7 and ESM Table 2).

Only one FIA was measured in fluorite of sample 1 (Fig. 7). Type 1 FIs in this sample ( $T_{\mathrm{h}}$ and salinities of 316-338 ${ }^{\circ} \mathrm{C}$ and 1.6 wt.\% equiv. $\mathrm{NaCl}$, respectively) show both $\mathrm{CO}_{2}$ homogenization of the liquid to the vapor phase, as well as vice versa, at temperatures between 30.3 and $30.5^{\circ} \mathrm{C}$, which is close to the critical temperature of $\mathrm{CO}_{2}$ (Fig. 6a).

Similar observations were made in sample 5 , where nine FIAs in total were measured in fluorite and cogenetic quartz (Fig. 7). The fourth FIA in quartz of sample 5 shown in Fig. 7 is the only one that includes cogenetic type 1, 2, and 


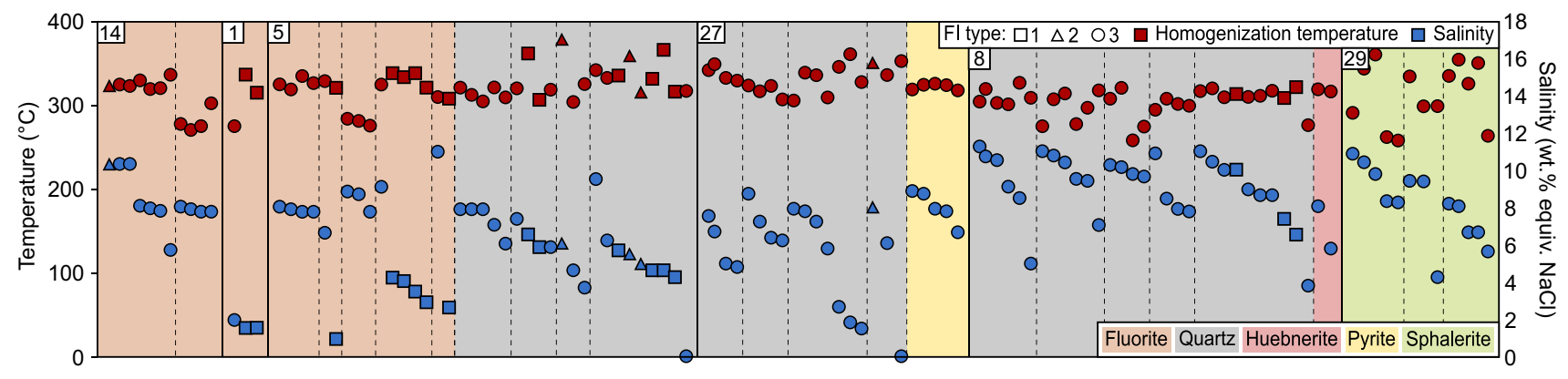

Fig. 7 Homogenization temperatures (red symbols) and salinities (blue symbols) of fluid inclusions in different ore and gangue minerals from the Detroit City portal of the Sweet Home mine, Colorado. Numbers refer to individual samples (locations of the samples 1, 5,
8, 14, 27, and 29 are shown in Fig. 5a). FIAs in different minerals are separated by dashed lines. Color codes refer to different minerals and symbols to FI types. For each assemblage, data are plotted in order of decreasing salinity to the right
3 FIs (the latter commonly showing clathrate melting). In this assemblage, $T_{\mathrm{h}}$ values vary between 315 and $367{ }^{\circ} \mathrm{C}$ and salinities range between 4.3 and $9.6 \mathrm{wt} \%$ equiv. $\mathrm{NaCl}$.

Sample 27 contains FIAs in cogenetic quartz and pyrite. In general, $T_{\mathrm{h}}$ values $\left(307-362^{\circ} \mathrm{C}\right.$ ) and salinities (mainly between 4.9 and $9.0 \mathrm{wt} \%$ equiv. $\mathrm{NaCl}$ ) are similar in both minerals. The same holds for FIs in sample 8, where FIs in cogenetic quartz and huebnerite mostly show $T_{\mathrm{h}}$ values between 296 and $328^{\circ} \mathrm{C}$ and salinities between 5.1 and $11.3 \mathrm{wt} \%$ equiv. $\mathrm{NaCl}$ (Fig. 7).

The microthermometric data of FIs in sphalerite (sample 29) are more variable than those in the other minerals. Values of $T_{\mathrm{h}}$ range between 260 and $361{ }^{\circ} \mathrm{C}$ and salinities vary from 4.3 to $11.0 \mathrm{wt} \%$ equiv. $\mathrm{NaCl}$. The $\mathrm{CO}_{2}$ contents of these FIs are also variable, as some show clathrate melting, whereas others do not. It is noteworthy that sphalerite is the only studied mineral where both melting of ice and clathrate were observed in individual FIs.

In summary, there are no systematic differences in the microthermometry data between gangue minerals (fluorite and quartz) and associated ore minerals (pyrite, huebnerite, and sphalerite).

\section{Laser Raman spectroscopy}

$\mathrm{CO}_{2}$ was the only gas species detected in Raman spectra from vapor-rich type 1 and 2 FIs and in gas bubbles from type 3 FIs (ESM Table 2). Solid crystals of anhydrite and calcite were identified in some FIs. Since no melting or dissolution behavior was observed during heating, it is likely that these solids were accidentally trapped (Fig. 6c, d).

\section{Fluid inclusion hydrogen and oxygen isotopic composition}

The results of fluid inclusion hydrogen and oxygen isotope analysis are presented in Fig. 8 and ESM Table 3. With $\delta^{2} \mathrm{H}_{\mathrm{w}}$ values from -70 to $-50 \%$ and $\delta^{18} \mathrm{O}_{\mathrm{w}}$ values from -2.0 to $7.6 \%$, FIs in samples of early-stage pyrite plot into or slightly to the left of the primary magmatic water box (Taylor 1974). Fluid inclusions in early-stage fluorites show more variable $\delta^{2} \mathrm{H}_{\mathrm{w}}$ and $\delta^{18} \mathrm{O}_{\mathrm{w}}$ values than those hosted in early-stage pyrite, but they plot on the same trend line between magmatic and meteoric water (Fig. 8). Inclusions in early-stage quartz yields lower $\delta^{2} \mathrm{H}_{\mathrm{w}}$ and $\delta^{18} \mathrm{O}_{\mathrm{w}}$ values (from -114.3 to $-94.8 \%$ and from -13.1 to $-10.0 \%$, respectively), which plot at the end of the trend line close to the meteoric water line (GMWL; Craig 1961). Earlystage huebnerite samples give remarkably low $\delta^{2} \mathrm{H}_{\mathrm{w}}$ values from -150.5 to $-133.5 \%$, which differ from all other studied minerals (Fig. 8).

The $\delta^{2} \mathrm{H}_{\mathrm{w}}$ values of FIs hosted in galena (from -115.7 to $-86.1 \%$ ), tetrahedrite-tennantite (from -122.0 to $-106.0 \%$ ), and chalcopyrite (from -99.2 to $-91.5 \%$ ) from the main sulfide stage are generally lower than those in early-stage minerals, whereas the $\delta^{18} \mathrm{O}$ values do not differ significantly. Altogether, the $\delta^{2} \mathrm{H}_{\mathrm{w}}$ and $\delta^{18} \mathrm{O}_{\mathrm{w}}$ data of samples from the main sulfide stage plot along a trend line that is approximately parallel to the early-stage mineral trend line (Fig. 8).

Main sulfide-stage quartz and late-stage rhodochrosite and fluorite consistently yield $\delta^{2} \mathrm{H}_{\mathrm{w}}$ and $\delta^{18} \mathrm{O}_{\mathrm{w}}$ values plotting close to the meteoric water line.

It must be noted that oxygen-bearing minerals, such as quartz, huebnerite, and rhodochrosite, may have experienced a post-depositional depletion in ${ }^{18} \mathrm{O}$ due to low-temperature isotope re-equilibration (e.g., Rye and O'Neil 1968; Uemura et al. 2020). Thus, the original $\delta^{18} \mathrm{O}_{w}$ value of these minerals may have been higher, and caution must be paid when interpreting the measured data.

\section{$\delta^{13} \mathrm{C}_{\mathrm{CO} 2}$ of fluid inclusion gas and carbon and oxygen isotope ratios of rhodochrosite}

The carbon isotopic composition of $\mathrm{CO}_{2}$ from FIs in earlystage fluorite and quartz as well as the carbon and oxygen isotopic compositions of rhodochrosite are shown in Fig. 9 


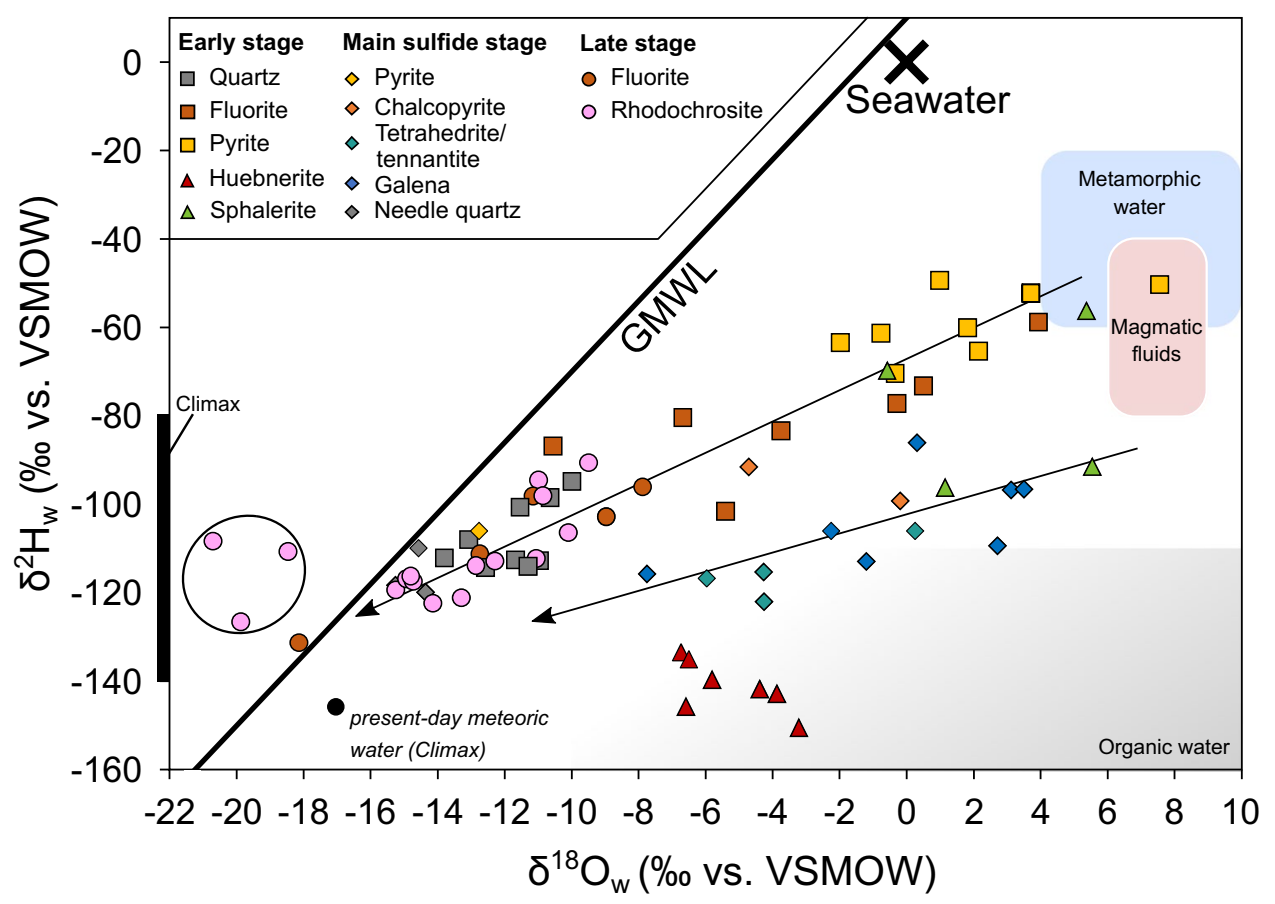

Fig. 8 Fluid inclusion hydrogen and oxygen isotope data of early-, main sulfide-, and late-stage ore and gangue minerals from the Detroit City portal of the Sweet Home mine, Colorado. Arrows represent possible fluid evolution paths, indicating the existence of at least two distinct fluid reservoirs and fluid mixing. The global meteoric water line (GMWL), which expresses the relation between $\delta^{2} \mathrm{H}_{\mathrm{w}}$ and $\delta^{18} \mathrm{O}_{w}$ in natural terrestrial waters as a global average (Craig 1961), the metamorphic and magmatic boxes (Taylor 1974), and the organic water box (Sheppard 1986), as well as a previously published $\delta^{2} \mathrm{H}_{\mathrm{w}}$

and ESM Table 3. The $\mathrm{CO}_{2}$ of FIs in early-stage fluorite and quartz has $\delta^{13} \mathrm{C}_{\mathrm{VPDB}}$ values between -7.2 and $-3.3 \%$ o (mean $-5.5 \%$ ). range from FIs in quartz and fluorite samples of different mineralization stages, and present-day meteoric water from Climax (Hall et al. 1974) are shown for reference. The circle on the left side marks rhodochrosite samples, of which the $\delta^{18} \mathrm{Ow}$ value is likely not primary and originally could have been higher. In general, fluid inclusions in oxygen-bearing minerals may experience a post-depositional depletion in ${ }^{18} \mathrm{O}$ due to temperature-forced isotope re-equilibration and therefore must be interpreted with care

The majority of DCP rhodochrosites and the gemmy rhodochrosites from the former SHP (Lüders et al. 2009) yielded a narrow range of $\delta^{13} \mathrm{C}_{\mathrm{VPDB}}$ values between -8.0
Fig. 9 Carbon and oxygen isotopic composition of rhodochrosite from the Detroit City portal of the Sweet Home mine, also showing literature $\mathrm{C}$ and $\mathrm{O}$ isotope values of rhodochrosite from the Sweet Home mine (Lüders et al. 2009). The range of $\mathrm{CO}_{2}$ carbon isotope composition of fluid inclusions in Detroit City portal early-stage fluorite and quartz is shown for comparison

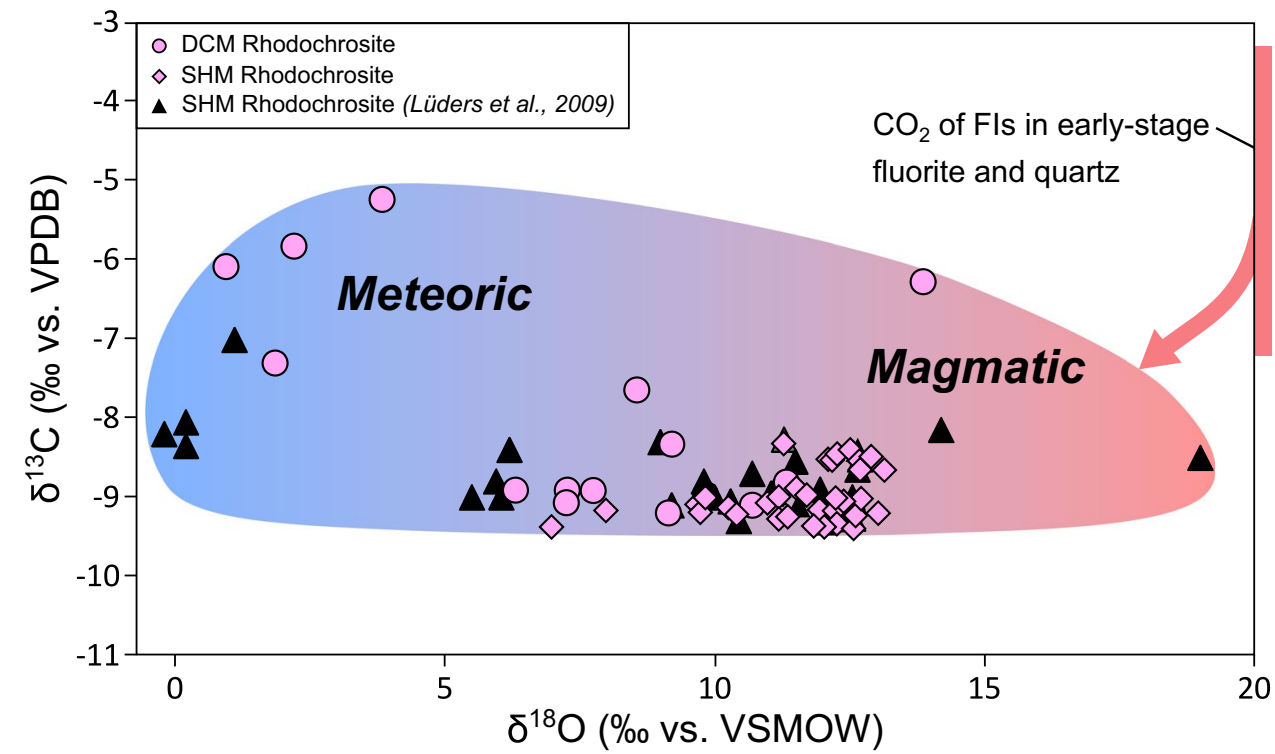


and $-9.2 \%$, which are lower than the FI range (Fig. 9). The $\delta^{18} \mathrm{O}_{\text {vSMOw }}$ values of rhodochrosites from the DCP and the former SHP are similar and both show a wider range of between 0.9 and $13.9 \%$.

\section{Noble gas elemental and isotopic composition}

The results of noble gas analyses of crush-released fluids in ore and gangue minerals from the DCP are shown in Fig. 10 and ESM Table 4.
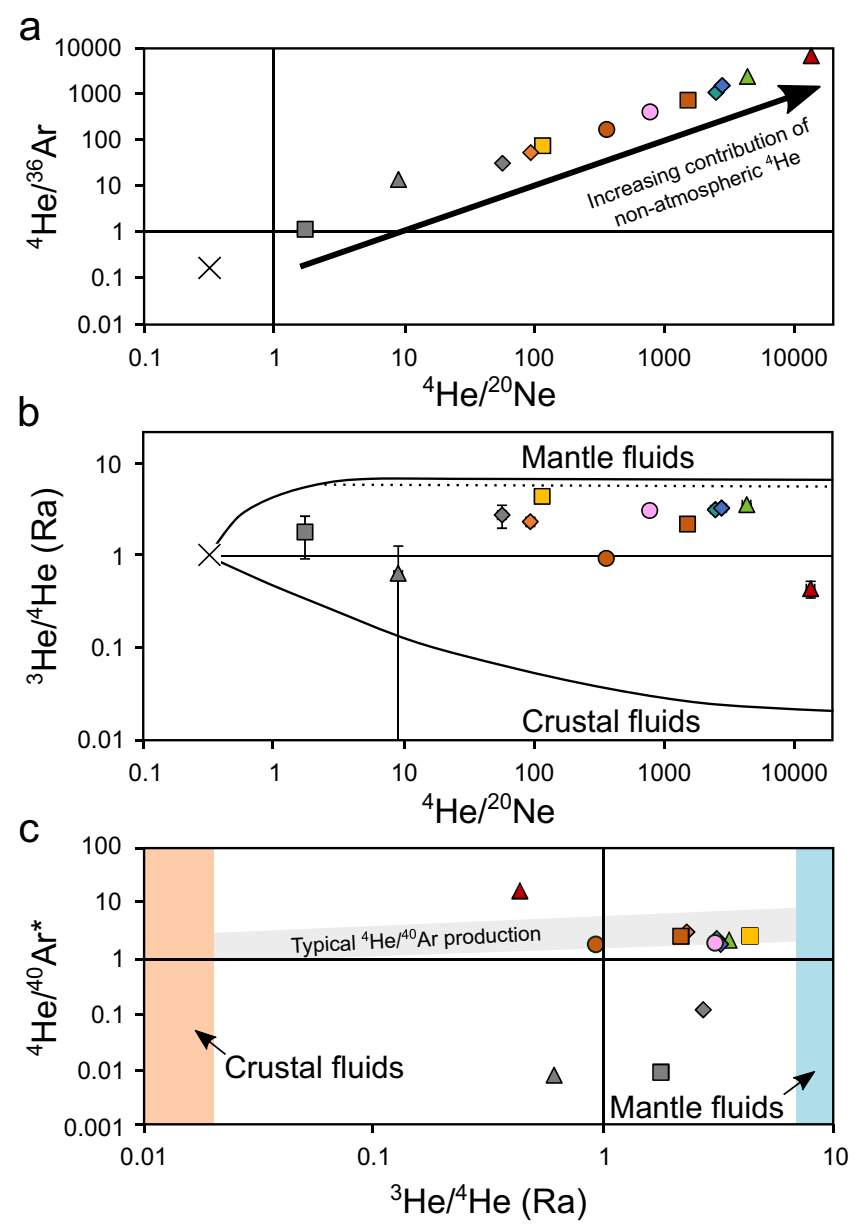

Fig. 10 Noble gas isotopic compositions of gases extracted from fluid inclusions in early-, main sulfide-, and late-stage ore and gangue minerals from the Detroit City portal of the Sweet Home mine, Colorado. Early-stage quartz that is intergrown with huebnerite is displayed as "Quartz (Hub)." (a) ${ }^{4} \mathrm{He} /{ }^{36} \mathrm{Ar}$ versus ${ }^{4} \mathrm{He} /{ }^{20} \mathrm{Ne}$ plot. A correlation from the atmospheric ratios $\left({ }^{4} \mathrm{He} /{ }^{36} \mathrm{Ar}=0.168\right.$ and $\left.{ }^{4} \mathrm{He} /{ }^{20} \mathrm{Ne}=0.319\right)$ to values up to four orders of magnitude higher reflects the increasing contribution of non-atmospheric (mantle or crustal) ${ }^{4} \mathrm{He}$. (b) ${ }^{3} \mathrm{He} /{ }^{4} \mathrm{He}$ versus ${ }^{4} \mathrm{He} /{ }^{20} \mathrm{He}$ plot $\left(\mathrm{Ra}\right.$ is the atmospheric ratio of $1.39 \times 10^{-6}$ ). Characteristic ${ }^{3} \mathrm{He} /{ }^{4} \mathrm{He}$ ratios of terrestrial reservoirs (1 Ra for the atmosphere, $0.02 \mathrm{Ra}$ for crustal fluids, $6.1 \mathrm{Ra}$ for subcontinental lithospheric mantle (black dotted line), and $>7 \mathrm{Ra}$ for shallow depleted

\section{Helium isotopic composition, $\mathrm{He} / \mathrm{Ne}$, and $\mathrm{He} / \mathrm{Ar}$ ratio}

Early-stage milky quartz samples (with ${ }^{4} \mathrm{He} /{ }^{36} \mathrm{Ar}$ from 1.2 to 13 and ${ }^{4} \mathrm{He} /{ }^{20} \mathrm{Ne}$ from 1.7 to 9.0 ) and main sulfide-stage quartz (with ${ }^{4} \mathrm{He} /{ }^{36} \mathrm{Ar}=31$ and ${ }^{4} \mathrm{He} /{ }^{20} \mathrm{Ne}=57$ ) are closest to the atmospheric values of these ratios (Fig. 10a). All other samples show values up to more than three orders of magnitude higher than the atmospheric value.

The ${ }^{3} \mathrm{He} /{ }^{4} \mathrm{He}$ versus ${ }^{4} \mathrm{He} /{ }^{20} \mathrm{Ne}$ plot shows that all SHM samples yielded a range of ${ }^{3} \mathrm{He} /{ }^{4} \mathrm{He}$ ratios between 0.43 and 4.3 Ra, with quartz and huebnerite from the same sample giving the lowest values of 0.43 and $\sim 0.6 \mathrm{Ra}$, respectively

d

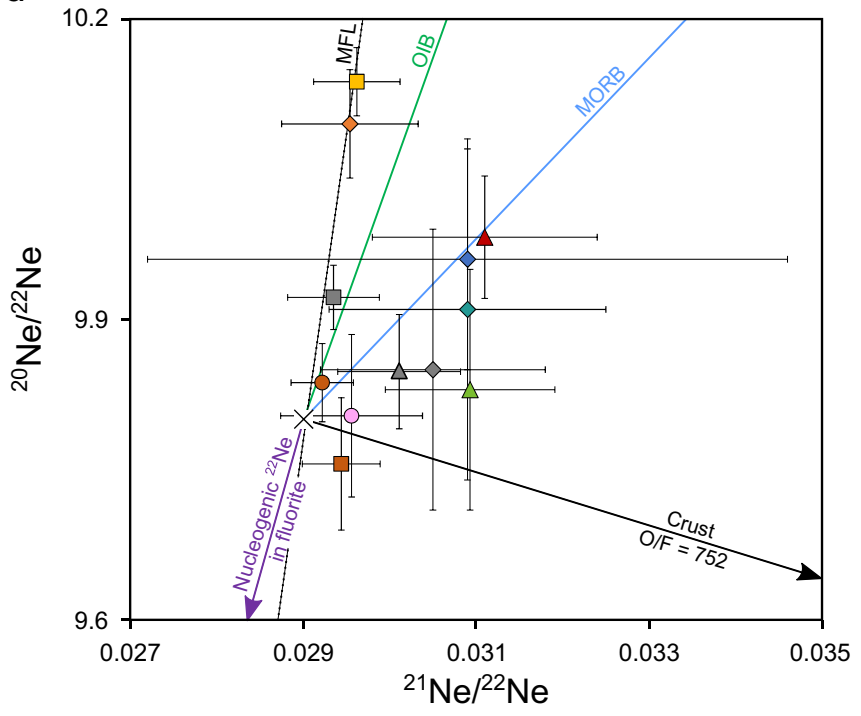

\begin{tabular}{|c|c|}
\hline \multirow{2}{*}{$\begin{array}{c}\times \text { Atmosphere } \\
\text { Early stage }\end{array}$} & Main sulfide stage \\
\hline & \multirow{5}{*}{$\begin{aligned} \diamond & \text { Chalcopyrite } \\
\diamond & \text { Tetrahedrite/ } \\
\text { tennantite } & \text { Galena } \\
\diamond & \text { Needle quartz } \\
& \text { Late stage }\end{aligned}$} \\
\hline 口 Milky quartz & \\
\hline$\square$ Fluorite & \\
\hline$\square$ Pyrite & \\
\hline$\Delta$ Huebnerite & \\
\hline$\Delta$ Quartz (Hub) & o Fluorite \\
\hline$\Delta$ Sphalerite & o Rhodochrosite \\
\hline
\end{tabular}

and primitive mantle-derived fluids) are also indicated. (c) ${ }^{4} \mathrm{He} /{ }^{40} \mathrm{Ar} *$ versus ${ }^{3} \mathrm{He} /{ }^{4} \mathrm{He}$ plot. ${ }^{4} \mathrm{He} /{ }^{40} \mathrm{Ar} *$ is a measure of the production ratio of ${ }^{4} \mathrm{He}$ from $\mathrm{U}$ and $\mathrm{Th}$ decay to ${ }^{40} \mathrm{Ar} *$ (* denotes correction for atmospheric ${ }^{40} \mathrm{Ar}$ ) from ${ }^{40} \mathrm{~K}$ decay. Only huebnerite shows anomalously high ${ }^{4} \mathrm{He} /{ }^{40} \mathrm{Ar} *$ and only quartz samples anomalously low ${ }^{4} \mathrm{He} /{ }^{40} \mathrm{Ar} *$. All other minerals plot in the typical production range. (d) ${ }^{20} \mathrm{Ne} /{ }^{22} \mathrm{Ne}$ versus ${ }^{21} \mathrm{Ne} /{ }^{22} \mathrm{Ne}$ plot. The lines that extend away from the atmosphere reflect mass fractionation (MFL; black dotted line), nucleogenic ingrowth in the crust with $\mathrm{O} / \mathrm{F}=752$ (black arrow), production of nucleogenic ${ }^{22} \mathrm{Ne}$ in $\mathrm{U}$ - and Th-bearing fluorite (purple arrow), or addition of mantle neon from the oceanic island (OIB; green line) and mid-ocean ridge basalts (MORB; blue line). See text for data sources 
(Fig. 10b). The ${ }^{3} \mathrm{He} /{ }^{4} \mathrm{He}$ ratio of late purple fluorite $(0.92 \mathrm{Ra})$ is also slightly lower than the atmospheric value. The ratios of other early-stage quartz $(\sim 1.8 \mathrm{Ra})$ and fluorite samples $(2.16 \mathrm{Ra})$, as well as main sulfide-stage quartz $(\sim 2.7 \mathrm{Ra})$ and late-stage rhodochrosite samples (3.03 Ra), are intermediate. Sulfide minerals including sphalerite, galena, and tetrahedrite-tennantite samples yielded a narrow range (3.1-3.5 Ra) with a low outlier for chalcopyrite $(2.3 \mathrm{Ra})$ and a high value for early-stage pyrite (4.3 Ra). Except for early-stage quartz $\left({ }^{4} \mathrm{He} /{ }^{20} \mathrm{Ne}=1.7\right)$, all minerals yield ${ }^{4} \mathrm{He} /{ }^{20} \mathrm{Ne}$ ratios $>9$ and up to 13,400 (huebnerite). The atmospheric He contribution is thus generally $<3.5 \%$.

Figure $10 \mathrm{c}$ presents the ratio of ${ }^{4} \mathrm{He}$ to excess radiogenic ${ }^{40} \mathrm{Ar} *$, after correction for atmospheric argon with ${ }^{40} \mathrm{Ar} /{ }^{36} \mathrm{Ar}=298.56$ (Lee et al. 2006). The ${ }^{4} \mathrm{He} /{ }^{40} \mathrm{Ar} *$ of the huebnerite sample (17) is at least a factor of two higher than the normal production ratios (resulting from $\mathrm{U}$, Th, and $\mathrm{K}$ decay) of 1-3 in the crust and 2-8 in the mantle (Ozima and Igarashi 2000). All sulfide samples, including early-stage pyrite, as well as early- and late-stage fluorite and rhodochrosite yielded typical crustal ${ }^{4} \mathrm{He} /{ }^{40} \mathrm{Ar} *$ ratios. In contrast, both early-stage quartz samples gave ${ }^{4} \mathrm{He} /{ }^{40} \mathrm{Ar} *$ ratios two orders of magnitude below the typical production ratio, and the main sulfide-stage quartz gave a ratio one order of magnitude smaller.

\section{Neon isotopic composition}

Figure 10d shows ${ }^{20} \mathrm{Ne} /{ }^{22} \mathrm{Ne}$ versus ${ }^{21} \mathrm{Ne} /{ }^{22} \mathrm{Ne}$, including characteristic trajectories for MORB (Sarda et al. 1988), OIB (Honda et al. 1991), average crust with $\mathrm{O} / \mathrm{F}=752$ (oxygen and fluorine elemental ratio) (Hünemohr 1989), the production of nucleogenic ${ }^{22} \mathrm{Ne}$ in $\mathrm{U}$ - and Th-bearing fluorite, and the (air) mass fractionation line. Due to the small deviations from atmospheric composition, error bars are relatively large and thus interpretations should be made with care. Nevertheless, earlystage pyrite and later chalcopyrite show the highest ${ }^{20} \mathrm{Ne} /{ }^{22} \mathrm{Ne}$ ratios (10.14 and 10.10, respectively), with ${ }^{21} \mathrm{Ne} /{ }^{22} \mathrm{Ne}$ values (0.0296 and 0.0295, respectively), close to the air ratio plotting on the air mass fractionation line. Most other ore minerals including huebnerite, sphalerite, tetrahedrite, and galena plot in a wide range between MORB and crustal values. The gangue minerals (quartz, fluorite, and rhodochrosite of all stages) tend to plot closer to the atmospheric ${ }^{20} \mathrm{Ne} /{ }^{22} \mathrm{Ne}$ and ${ }^{21} \mathrm{Ne} /{ }^{22} \mathrm{Ne}$ ratios (9.8 and 0.029 , respectively) with ${ }^{20} \mathrm{Ne} /{ }^{22} \mathrm{Ne}$ ranging between 9.8 and 9.9 and ${ }^{21} \mathrm{Ne} /{ }^{22} \mathrm{Ne}$ between 0.029 and 0.031 .

\section{Argon isotopic composition}

The ${ }^{40} \mathrm{Ar} /{ }^{36} \mathrm{Ar}$ ratios are highly variable between air-like (296, e.g., Ozima and Podosek 2002) and a maximum value of 1876, indicating variable crustal or mantle contributions (ESM Table 4). Early-stage pyrite and main sulfide-stage chalcopyrite have ${ }^{40} \mathrm{Ar} /{ }^{36} \mathrm{Ar}$ ratios close to the atmospheric value. They are followed by higher ratios of the late-stage fluorite, early-stage quartz, rhodochrosite, main sulfide-stage quartz, and early-stage fluorite with ${ }^{40} \mathrm{Ar} /{ }^{36} \mathrm{Ar}$ ratios between 388 and 574. Early-stage quartz from the huebnerite sample, however, yielded the highest ${ }^{40} \mathrm{Ar} /{ }^{36} \mathrm{Ar}$ ratio of 1876. Huebnerite, tetrahedrite-tennantite, galena, and sphalerite gave intermediate ${ }^{40} \mathrm{Ar} /{ }^{36} \mathrm{Ar}$ values between 574 and 1350.

\section{Noble gas elemental abundances}

Heavy noble gas elemental abundances are useful to test for isotopic equilibrium at the ca. $250-330{ }^{\circ} \mathrm{C}$ mineralization temperature indicated by fluid inclusions. Elemental fractionation factors $\left(F_{i}=\left({ }^{i} X /{ }^{36} \mathrm{Ar}\right)_{\text {sample }} /\left({ }^{i} X /{ }^{36} \mathrm{Ar}\right)_{\text {air }}\right.$, where ${ }^{i} X={ }^{20} \mathrm{Ne},{ }^{84} \mathrm{Kr}$ or $\left.{ }^{132} \mathrm{Xe}\right)$ are compared with those for airsaturated water calculated for temperatures from 0 to $330{ }^{\circ} \mathrm{C}$ (Crovetto et al. 1982; Smith and Kennedy 1983). The results are displayed in ESM Fig. 3, with ESM Fig. 3a showing early-stage mineral data and ESM Fig. 3b main sulfide- and late-stage mineral data. Helium isotope data are not displayed as they are dominated by non-atmospheric components and would plot well above the shown range. In all samples, Ne abundances are too high for equilibrium at the mineralization temperature. On the other hand, early-stage quartz, pyrite, huebnerite and sphalerite, and main sulfidestage chalcopyrite and rhodochrosite do plot along the $\mathrm{Kr}$ equilibrium curves for 250 and $330{ }^{\circ} \mathrm{C}$. This is also true for the Xe $250{ }^{\circ} \mathrm{C}$ equilibrium curve, regarding early-stage pyrite. Generally, however, most samples do not plot on heavy noble gas equilibrium curves, which may be related to the fact that $>100{ }^{\circ} \mathrm{C}$ fractionation curves (Crovetto et al. 1982) only apply to freshwater and do not consider salinities. Nevertheless, the fractionation plots show that the heavy noble gases have a significant non-magmatic component.

\section{Sulfur isotopic composition}

Sulfide minerals from the DCP yielded $\delta^{34} \mathrm{~S}$ values between -3.4 and + 1.6\% (Fig. 11, ESM Table 5). The highest $\delta^{34} \mathrm{~S}$ values were measured in early-stage pyrite (0.9 to $1.6 \%$ ) and molybdenite (1.3 to $1.4 \%$ ). Sphalerite from the late greisen stage and pyrite from the main sulfide stage gave slightly lower $\delta^{34} \mathrm{~S}$ values $(0.3$ to $1.2 \%$ ), and the ranges for the other main sulfide-stage sulfides overlap between -3.4 and $+0.2 \%$.

\section{Interpretations}

\section{P-T conditions of fluid entrapment in quartz and fluorite from the early stage}

The early-stage mineralization of the SHM formed from fluids with salinities up to $12 \mathrm{wt} \%$ equiv. $\mathrm{NaCl}$ in the presence of 
Fig. 11 Boxplot showing sulfur isotopic compositions of Detroit City portal (colored boxes with black contours) early- and main sulfide-stage sulfides. Sweet Home mine data (gray boxes) of Lüders et al. (2009) are shown for comparison

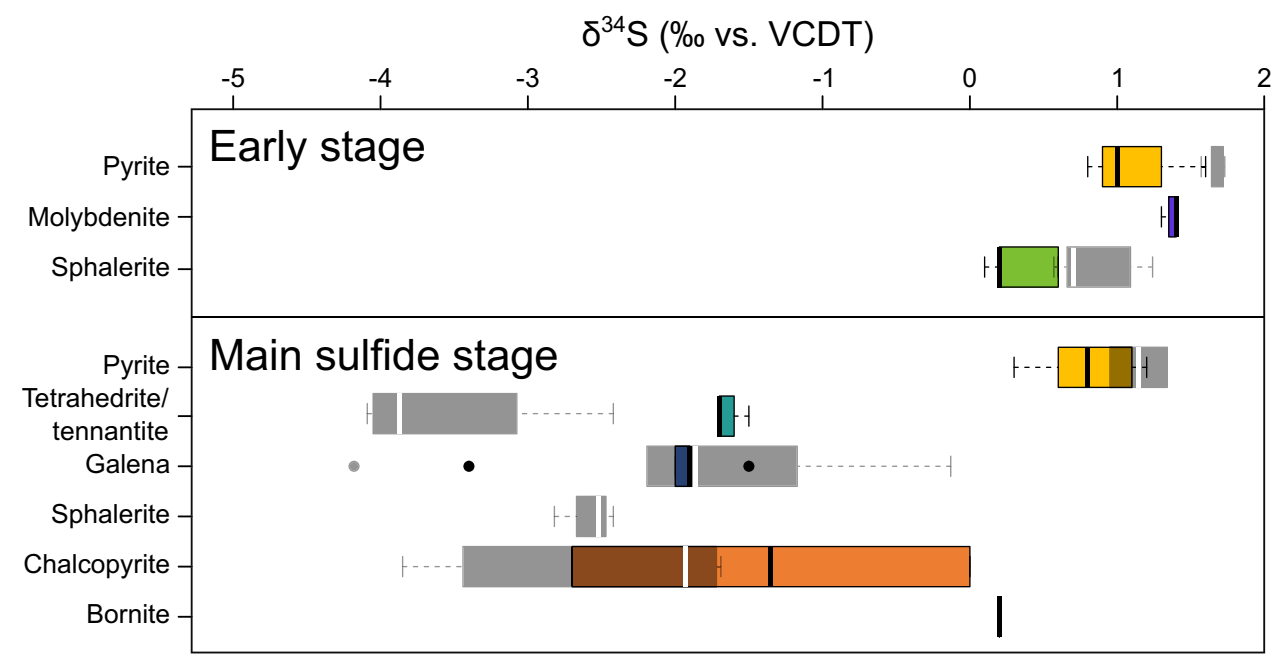

$\mathrm{CO}_{2}$. Values of $T_{\mathrm{h}}$ for FIs hosted in fluorite and quartz average at about $320^{\circ} \mathrm{C}$. Solvi and isochores of individual carbonic three-phase type 1 FIs were calculated using the computer program "Fluid inclusions in the system $\mathrm{H}_{2} \mathrm{O}-\mathrm{NaCl}-\mathrm{CO}_{2}$ : An algorithm to determine composition, density and isochore" by Steele-MacInnis (2018). The results show that the majority of these FIs were trapped at temperatures between 360 and $415^{\circ} \mathrm{C}$ and pressures between 1050 and 1750 bar (ESM Fig. 4). Similar P-T conditions were estimated for carbonic three-phase type 1 FIs from the former SHM workings and interpreted as a result of an originally homogeneous fluid intersecting the solvus during cooling or decompression (Lüders et al. 2009). This may be supported by the relatively narrow range in composition of carbonic three-phase type 1 FIs (Lüders et al. 2009, this study), suggesting that the P-T fluid pathway intersected the solvus near its crest, where the composition of the two immiscible phases did not differ significantly if immiscibility occurred (Bodnar et al. 1985; Diamond 1994). Alternatively, a fluctuating pressure regime from lithostatic to hydrostatic conditions or fluid entrapment from heterogeneous mixtures of two fluids of different origins may explain the phase transitions of type 1 inclusions to the liquid phase or to the vapor phase (Lüders et al. 2009; Fig. 6a).

\section{Fluid inclusion hydrogen and oxygen isotopic composition}

Variations of $\delta^{2} \mathrm{H}_{\mathrm{w}}$ and $\delta^{18} \mathrm{O}_{\mathrm{w}}$ in fluid hosted by different minerals are interpreted to reflect different mixing trends between a magmatic fluid and meteoric water (Fig. 8 and ESM Table 3 ). The conspicuously low $\delta^{2} \mathrm{H}_{\mathrm{w}}$ values of early-stage huebnerite samples may point to an organicrich fluid source (Sheppard 1986). The $\delta^{2} \mathrm{H}_{\mathrm{w}}$ and $\delta^{18} \mathrm{O}_{\mathrm{w}}$ data also suggest the cessation of the magmatic fluid input during the late mineralization stage (i.e., pink rhodochrosite, purple fluorite).

\section{$\delta^{13} C_{\mathrm{CO} 2}$ of fluid inclusion gas and carbon and oxygen isotope ratios of rhodochrosite}

The $\delta^{13} \mathrm{C}_{\mathrm{CO} 2}$ values of type 1 aqueous carbonic and type 2 vapor-rich $\mathrm{CO}_{2}$ FIs in early quartz and fluorite suggest that carbon was derived from a magmatic source (Hoefs 2018 and references therein). The slightly lower $\delta^{13} \mathrm{C}$ of rhodochrosites compared to $\delta^{13} \mathrm{C}_{\mathrm{CO} 2}$ values of $\mathrm{FI}$ gas can be explained by temperature-dependent carbon isotope fractionation between $\mathrm{CO}_{2}$ and carbonates (Hoefs 2018 and references therein). Whereas $\delta^{13} \mathrm{C}$ values of rhodochrosite are relatively constant, the $\delta^{18} \mathrm{O}$ data are more variable and suggest mixing of magmatic and meteoric fluids (Fig. 9).

\section{Noble gases}

While the noble gas data are complex, they indicate that the atmospheric helium contribution was generally less than $3.5 \%$ (Fig. 10a, b). Neon (Fig. 10d) and argon isotopic compositions (ESM Table 4), however, may represent variable mixtures of atmospheric, crustal, and mantle components and are additionally affected by minor mass fractionation.

The ${ }^{3} \mathrm{He} /{ }^{4} \mathrm{He}$ ratios span a relatively broad range between the crustal and mantle endmembers, however mostly closer to the mantle field, which indicates mixing of different fluid sources (Fig. 10b).

Fluid inclusions hosted in huebnerite from the DCP, however, dominantly show ${ }^{3} \mathrm{He} /{ }^{4} \mathrm{He}$ and ${ }^{4} \mathrm{He} /{ }^{40} \mathrm{Ar} *$ ratios that are typical for, or may be explained by, crustal fluids (Fig. 10b and Fig. 10c, respectively). Anomalously high ${ }^{4} \mathrm{He} /{ }^{40} \mathrm{Ar} *$ ratios may indicate production in a high $(\mathrm{U}+\mathrm{Th}) / \mathrm{K}$ environment or fractionation of $\mathrm{He}$ and $\mathrm{Ar}$, e.g., by melt formation, degassing, solution (temperature dependent), or diffusion, in an upper crustal reservoir (Ozima and Podosek 2002). Rocks enriched in uranium, such as organic-rich sedimentary rocks or granites and granitic gneisses, are present in 
the study area as discussed in more detail in the following chapter. All sulfides, including early-stage pyrite, as well as early- and late-stage fluorite and rhodochrosite plot in the range of typical crustal ${ }^{4} \mathrm{He} /{ }^{40} \mathrm{Ar} *$ ratios and thus may indicate closed-system conditions with respect to noble gases (Ozima and Podosek 2002). The ${ }^{4} \mathrm{He}^{40} \mathrm{Ar}^{*}$ ratios of FIs in quartz samples are smaller than the range of typical production ratios, indicating He loss (Fig. 10c).

\section{Sulfur isotopic composition}

The isotopic variation of sulfur can depend on changes in physico-chemical conditions or mixing of sulfur from distinctly different sources (Ohmoto and Rye 1979). Assuming ore-formation temperatures of at least $400{ }^{\circ} \mathrm{C}$ for early-stage sulfides, such as molybdenite, pyrite, and sphalerite (Lüders et al. 2009; this study), the calculated initial $\delta^{34} \mathrm{~S}$ values of the ore fluid would range within 0 and $0.9 \%$ and may point to a homogeneous (probably magmatic) sulfur source (Ohmoto and Rye 1979). For ore minerals of the main sulfide stage that precipitated at lower temperatures (ca. $300{ }^{\circ} \mathrm{C}$; Lüders et al. 2009), the calculated range of $\delta^{34} \mathrm{~S}$ values is considerably larger (from 1.8 to $-3.7 \%$; Ohmoto and Rye 1979). The calculated ranges confirm the overall trend of the $\delta^{34} \mathrm{~S}$ raw data (Fig. 11).

Assuming a homogeneous (probably magmatic) sulfur source for sulfides that precipitated during the early stage and main sulfide stage, significant changes in $f \mathrm{O}_{2}$ and $\mathrm{pH}$ would have been required to explain the variation of $\delta^{34} \mathrm{~S}$ values of sulfides during ore deposition (Ohmoto and Rye 1979). At low $f_{2}$ and $\mathrm{pH}$ values, the $\delta^{34} \mathrm{~S}$ values of sulfides will not show significant fractionation compared to the initial $\delta^{34} \mathrm{~S}$ value of the fluid. In contrast, at high $\mathrm{fO}_{2}$ values, the $\delta^{34} \mathrm{~S}$ values of sulfides differ significantly from the initial $\delta^{34} \mathrm{~S}$ value of the ore fluid and the proportions of aqueous sulfate in the fluid increases (Ohmoto and Lasaga 1982). Given that sulfates are absent but rhodochrosite is abundant in the main sulfide stage, significant changes of $f \mathrm{O}_{2}$ and $\mathrm{pH}$ may be precluded and we assume a homogeneous fluid source. Therefore, the decreasing $\delta^{34} \mathrm{~S}$ values of the sulfides from the main sulfide stage are best explained by mixing of sulfur from different sources. These can be magmatic and sedimentary sulfur sources, the latter covering a wider range, especially for organic-rich sediments that may have negative $\delta^{34} \mathrm{~S}$ values (Hoefs 2018 and references therein).

\section{Discussion}

The results of this study are not compatible with an exclusive magmatic origin of deep hydrothermal vein-type mineralization for Climax-type ore deposits in the CMB as proposed by previous research (Wallace et al. 1978; Mutschler et al.
1981; Westra and Keith 1981; White et al. 1981; Stein and Hannah 1985; Bookstrom et al. 1988; Carten et al. 1988, 1993; Stein 1988; Keith et al. 1993; Cline and Bodnar 1994; Lowenstern 1994; Wallace 1995; Seedorff and Einaudi 2004a; 2004b; Klemm et al. 2008; Ludington and Plumlee 2009; Audétat 2010, 2015; Pettke et al. 2010; Audétat et al. 2011; Mercer et al. 2015; Audétat and Li 2017). Instead, the new data reported here from FI studies and stable isotope analysis of FIs, sulfides, and rhodochrosite give compelling evidence for variable mixing proportions of magmatic fluids with heated meteoric water during the evolution of the hydrothermal system at the DCP. This includes early-stage greisen and pyrite veins as well as greisen and phyllic alteration assemblages (i.e., fluorite, quartz, pyrite, huebnerite, and sphalerite), and main sulfide stage mineral assemblages (i.e., base metal sulfides and rhodochrosite) as well as latestage mineralization (i.e., rhodochrosite and fluorite). Mixing models of magmatic and meteoric water have also been proposed by previous FI studies of Climax-type Mo deposits and associated hydrothermal systems (Hall et al. 1974; Bloom 1981; Smith 1983; Lüders et al. 2009; Rowe 2012).

\section{Fluid inclusion characteristics of Climax-type Mo deposits}

Studies of FIs in quartz and fluorite from Climax-type deposits (Climax, Hall et al. 1974; Questa, Bloom 1981; Smith 1983; Cline and Bodnar 1994; Klemm et al. 2008; Rowe 2012; Henderson, White et al. 1981; Seedorff and Einaudi 2004b) show great similarities in FI types. In general, four major types of FIs can be classified (Table 2). These are (i) carbonic three-phase, low-salinity to intermediate-salinity (130-400 ${ }^{\circ} \mathrm{C}, 0-10 \mathrm{wt} \%$ equiv. $\mathrm{NaCl}$ ), (ii) vapor-rich, lowto high-salinity $\left(300-500{ }^{\circ} \mathrm{C}, 0-20 \mathrm{wt} \%\right.$ equiv. $\mathrm{NaCl}$ ), (iii) liquid-rich, low- to high-salinity $\left(300-500{ }^{\circ} \mathrm{C}, 0-25 \mathrm{wt} \%\right.$ equiv. $\mathrm{NaCl}$ ), and (iv) multi-phase hypersaline $\left(180-450{ }^{\circ} \mathrm{C}\right.$, $30-65 \mathrm{wt} \%$ equiv. $\mathrm{NaCl}$ ) FIs. Although type 4 FIs have not been observed in studied minerals from the SHM (Reynolds 1998; Lüders et al. 2009; this study), type 1 to type 3 FIs are analogous to those observed in other Climax-type systems and their abundance suggests a similar fluid source and mechanism for ore formation at Climax-type deposits and the SHM. Whereas type 3 FIs are hosted in minerals from all ore stages of Climax-type deposits, type 1,2, and 4 FIs are restricted to the main stage of Mo mineralization (quartzmolybdenite stockwork veins, magmatic-hydrothermal breccias with a quartz-fluorite matrix, potassic alteration) and subsequent Mo mineralization (phyllic and greisen alteration and veins). Mo-bearing greisen veins, which are typically found inside intrusive porphyry complexes, also occur in distal deep hydrothermal veins at the DCP.

Our data show that $\mathrm{CO}_{2}$ contents of vapor-rich, $\mathrm{CO}_{2}$-bearing FIs, liquid $\mathrm{CO}_{2}$-bearing FIs, and liquid-rich 
FIs may vary considerably within the same assemblage, whereas evidence for phase separation is lacking. Based on elevated $\mathrm{Cu}$ contents in FIs and depletion in other metals, Lüders et al. (2009) suggested that phase separation may have occurred at a greater depth beneath the actual Sweet Home workings. Boiling at depth would also explain the absence of halite-bearing type 4 FIs in minerals from veintype mineralization of the SHM.

\section{Fluid mixing}

The mixing of magmatic fluids with meteoric water forming the early-stage greisen and pyrite veins as well as greisen and phyllic alteration, and the main sulfide stage veins as well as late-stage mineralization at the SHM, is evidenced by well-defined trends of fluid inclusion and bulk mineral isotope data. Note that all studied samples were carefully evaluated for fluid inclusion petrology prior to bulk analysis to avoid contamination by abundant secondary inclusions (for details, see "Reliability of fluid inclusion bulk analysis" section of the "Samples and analytical methods" chapter). Fluid inclusion water in pyrite samples from early-stage mineralization plots in or close to the primary magmatic fluid box (Taylor 1974), while combined hydrogen and oxygen isotope compositions of fluid inclusions hosted in early-stage quartz and fluorite (locally associated with molybdenite) and later sulfides follow a mixing trend of magmatic fluids with meteoric water (Fig. 8). A similar evolution of hydrogen and oxygen isotope ratios of FIs was observed at the Questa rhyolitic porphyry Mo deposit (New Mexico) and interpreted in terms of a mixing model of early magmatic fluids that were progressively diluted by meteoric water (Rowe 2012). Alternatively, several alteration processes (e.g., exchange reactions, hydration reactions, membrane filtration) may be responsible for the variation of $\mathrm{H}$ and $\mathrm{O}$ isotopes (e.g., Hoefs 2018 and references therein). However, given the lower sensitivity of $\mathrm{H}$ isotopes to alteration processes (e.g., Hoefs 2018 and references therein), our preferred interpretation is mixing of different sources for the mineralizing fluids.

The mixing of fluids from different sources is supported by $\delta^{13} \mathrm{C}_{\mathrm{CO} 2}$ values of FIs in quartz and fluorite from the early stage and slightly lower $\delta^{13} \mathrm{C}$ of rhodochrosites, indicating a magmatic carbon source, as well as by the more variable $\delta^{18} \mathrm{O}$ data, suggesting a mixed magmatic-meteoric origin. A magmatic carbon source, but mixed magmaticmeteoric oxygen source, was also proposed for calcite at Questa (Rowe 2012).

The sulfur isotopic composition of SHM sulfides and sulfosalts shows a development from homogeneous magmatic $\delta^{34} \mathrm{~S}$ values in the early stage towards more variable $\delta^{34} \mathrm{~S}$ values in the main sulfide stage. This trend may reflect a mixed magmatic-sedimentary source. There are similar findings from polymetallic vein mineralization found at the
Sn-W Mole Granite, Australia (Heinrich et al. 1992; Audétat et al. 2000). Lüders et al. (2009) showed that there is a correlation between decreasing $\delta^{34} \mathrm{~S}$ values and increasing ${ }^{206} \mathrm{~Pb} /{ }^{204} \mathrm{~Pb}$ in galena, which was explained by fluid/rock interaction between meteoric fluids and crustal rocks. Furthermore, it is conspicuous that the sulfides with lower $\delta^{34} \mathrm{~S}$ values from the main sulfide stage also yield lower $\delta^{2} \mathrm{H}_{\mathrm{w}}$ values of FI water than sulfides from the early stage, which suggests either multiple fluid sources or (minor) variations in $\delta^{2} \mathrm{H}_{\mathrm{w}}$ and $\delta^{18} \mathrm{O}_{\mathrm{w}}$ values of the magmatic fluid endmember with time.

Progressive dilution of magmatic fluids enriched in volatiles $\left(\mathrm{CO}_{2}, \mathrm{H}_{2} \mathrm{~S}\right.$, noble gases) by increasing amounts of meteoric water from the early to the late stage of mineralization is consistent with the continuously decreasing temperatures, pressures, $\mathrm{CO}_{2}$ concentrations, and variations in noble gas and $\mathrm{C}, \mathrm{O}, \mathrm{H}$, and $\mathrm{S}$ isotope ratios. The progressive mixture of $\mathrm{CO}_{2}$-poor meteoric fluids into the system may explain why liquid $\mathrm{CO}_{2}$-bearing FIs exclusively occur in early-stage minerals and are not observed in ore and gangue minerals of the subsequent sulfide stage (Reynolds 1998; Lüders et al. 2009). The absence of detectable $\mathrm{CO}_{2}$ in FIs with progressive mineralization was also reported from many Chinese Mo deposits (e.g., Yang et al. 2015; Zhou et al. 2015; Zhang et al. 2016; Xiong et al. 2018).

\section{The magmatic input}

Considering a progressive development towards lower $\delta^{34} \mathrm{~S}$ values from pyrite of the early stage to younger sulfides of the main sulfide stage, the highest $\delta^{34} \mathrm{~S}$ values around $1.7 \%$ measured in early-stage minerals may represent the magmatic sulfur value (Ohmoto and Rye 1979), which was already concluded for other Climax-type deposits (Stein and Hannah 1985; Stein 1988; Rowe 2012). Due to the low sulfur solubility in rhyolitic melts (Wallace and Edmonds 2011), it was proposed that the sulfur from the Henderson rhyolitic porphyry Mo deposit (Colorado) originated from a relatively small volume of underlying mantle-derived lamprophyre magma (Mercer et al. 2015). Over the last decades, bimodal magmatism with a mantle contribution was considered to be a likely source for melts associated with the formation of Climax-type Mo deposits during continental rifting (Westra and Keith 1981; Carten et al. 1993; Keith et al. 1993; Audétat 2010; Mercer et al. 2015).

Noble gas data may be a promising tool to distinguish between possible fluid sources and this study presents the first of their kind for the CMB. Helium isotopic compositions of fluid inclusions hosted in minerals from the SHM (Fig. 10b) support the idea that magmatic fluids had a substantial mantle component (except huebnerite, which is discussed in detail in the "Fluid-rock interaction" section). The ${ }^{3} \mathrm{He} /{ }^{4} \mathrm{He}$ isotope ratios of FIs hosted in early-stage 
pyrite from the DCP are 4.3 Ra. Considering binary mixing between the subcontinental lithospheric mantle (6.1 Ra, Gautheron and Moreira 2002) and continental lithosphere (0.02 Ra, Graham 2002) with:

$4_{\mathrm{He}_{\text {mantle }}}(\%)=100\left[\frac{\left(\frac{3_{\mathrm{He}}}{4_{\mathrm{He}}}\right)_{\text {sample }}-\left(\frac{3_{\mathrm{He}}}{4_{\mathrm{He}}}\right)_{\text {crust }}}{\left(\frac{3_{\mathrm{He}}}{4_{\mathrm{He}}}\right)_{\text {mantle }}-\left(\frac{3_{\mathrm{He}}}{4_{\mathrm{He}}}\right)_{\text {crust }}}\right]$

a contribution of up to $70 \%$ mantle He during the early stage and up to $50 \%$ for the main sulfide stage at the SHM can be estimated. The dominant mantle He contributions characteristic for the mineralization at the SHM differ significantly, e.g., from mantle He contributions of 4-20\% inferred for North American porphyry copper deposits (Kendrick et al. 2001) and $0.2-41 \%$ for Chinese Mo porphyry deposits (e.g., Bangpu Mo-Cu deposit, Wang et al. 2015; Daheishan and Luming Mo deposits, Zeng et al. 2018; Dasuji Mo deposit, Chen et al. 2021). The mantle gas involved in the formation of the Chinese Mo porphyry deposits was assumed to have derived from unstable mantle flows in convergent regimes (Zeng et al. 2018) and from upwelling asthenospheric mantle in post-collisional rifts (Wang et al. 2015; Chen et al. 2021). The latter is similar to the CMB, which was overprinted by the Rio Grande rift extension beginning ca. $33 \mathrm{Ma}$ (Chapin 2012 and references therein).

Intermediate $\delta^{13} \mathrm{C}$ values between -3.3 and $-7.2 \%$ for $\mathrm{CO}_{2}$ from FIs in early-stage quartz and fluorite may support a significant mantle $\mathrm{CO}_{2}$ contribution. Continental rift zones have repeatedly been associated with unusually carbon-rich mantle-derived magmas (Bailey 1987; Bailey and Macdonald 1987; Bailey and Hampton 1990). A melt inclusion study on the Pine Grove rhyolitic porphyry Mo deposit (Utah; Lowenstern 1994) yielded $\mathrm{CO}_{2}$ saturation pressures as high as $4300 \mathrm{bar}$, which correspond to a depth of $16 \mathrm{~km}$ for the beginning of volatile exsolution during ascent to depths of 2-3 km (depth of porphyry emplacement). The exsolution of a $\mathrm{CO}_{2}$ vapor phase from magma promotes the concentration of sulfur and noble gases (Lowenstern 2001; Scaillet and Pichavant 2005). Generally, such a vapor phase has low density (Papale and Polacci 1999). $\mathrm{CO}_{2}$ effervescence may explain the heterogeneous supply of $\mathrm{CO}_{2}$ to the early-stage ore-forming fluid in the SHM.

In summary, we conclude that $\mathrm{CO}_{2}$, noble gases, and early-stage sulfur are derived by mantle degassing (e.g., of a lamprophyric intrusion at depth) rather than originating from the rhyolitic melts. This observation is in concordance with findings about the origin of $\mathrm{S}$ and $\mathrm{CO}_{2}$ at the Henderson Mo porphyry deposit (Mercer et al. 2015). However, our data do not prove whether metals such as Mo, W, and base metals originate from magmatic fluids derived from rhyolitic melts or leaching of country rocks.

\section{Fluid-rock interaction}

Various Mo- and W-bearing lithologies have been deposited over the last $1700 \mathrm{Ma}$ in the CMB. This includes several Precambrian pegmatites in the Climax area (e.g., Platte Gulch, Buckskin Gulch, and Quandrary Peak), the Precambrian Silver Plume Granite, and the metasedimentary rocks of the Idaho Springs Formation in the Urad-Henderson area as well as numerous Precambrian scheelite occurrences in calcareous hornblendebearing layers of metamorphic rocks across the CMB (Tweto 1960; Zahony 1968; Wallace et al. 1978; Theobald et al. 1983).

Molybdenum in Climax-type ore deposits is likely directly derived from fluids that were expelled from magmas, which either formed by partial melting of lower or upper crustal rocks (Wallace et al. 1978; DePaolo 1981; Stein and Hannah 1985; Bookstrom et al. 1988; Stein 1988; Audétat et al. 2011; Mercer et al. 2015) or developed from a Mo-enriched mantle source (Westra and Keith 1981). Mixed mantle and crustal sources for the formation of Climax-type Mo deposits were also considered (White et al. 1981; Pettke et al. 2010). However, it has been shown that melt inclusions in quartz from Climax-type rhyolitic porphyry intrusions are Mo-poor with 5-10-ppm Mo mainly (Lowenstern 1994; Audétat et al. 2011; Audétat 2015; Mercer et al. 2015; Audétat and Li 2017), while the Mo content of the magmatic bulk fluid is estimated to be $100 \mathrm{ppm}$ (Audétat 2015). Lowenstern (1994) and Audétat (2015) therefore suggested the exsolution of large volumes of a fluid that originated from a low-density fluid-rich magma and circulated through semicrystallized narrow stocks and apophyses underneath the ore bodies. The focused flow of these high fluid volumes through a small rock volume is assumed to be the principal trigger for ore formation (Audétat and Li 2017).

Another mechanism for the accumulation of metals in ore fluids is the leaching of metals from country rocks. Smith (1983) considered that ore precipitation in porphyry Mo deposits resulted from the cooling of ore-forming fluids by interaction with the country rocks. Seedorff and Einaudi (2004b) suggested selected leaching of metals, namely Na, $\mathrm{K}$, and $\mathrm{Fe}$, from the country rocks, whereas Mo and base metals are derived from the rhyolitic melts. In contrast, significant leaching of metals (excluding Mo) from lower crustal rocks by circulating hot fluids in the Alma district and of Early Proterozoic rocks elsewhere in the CMB was proposed based on radiogenic isotope compositions of ore and gangue minerals (Kelley et al. 1998; Lüders et al. 2009).

Alteration and leaching of crustal rocks are also evidenced by the presence of nitrogen in huebnerite-hosted FIs (Lüders et al. 2009). The authors considered that nitrogen was either derived from decrepitated FIs in the crystalline basement rocks, $\mathrm{NH}_{4}{ }^{+} / \mathrm{K}^{+}$exchange reactions during fluid-rock interaction with feldspars and/or micas at elevated temperatures and subsequent mixing with oxygen-rich meteoric waters (Honma and Itihara 1981; Pöter et al. 2004), or thermal 
degradation of the organic matter during diagenetic processes (Jia and Kerrich 1999; Mingram and Bräuer 2001). The latter has also been proposed for the origin of $\mathrm{N}_{2}$ at the Logrosán Sn-W deposit in the Central Iberian Zone (Chicharro et al. 2016). The extremely negative $\delta^{2} H_{w}$ values of huebneritehosted FIs point to a non-(exclusive) magmatic fluid origin, possibly indicating an organic-rich source (Fig. 8). This could be shales or biotite schist; the latter is the host rock of the mineralization at the SHM. The relatively low $\delta^{2} \mathrm{H}_{\mathrm{w}}$ values (Fig. 8) and decreasing $\delta^{34} \mathrm{~S}$ values (Fig. 11) of sulfides from the main sulfide stage may also reflect considerable hydrogen and sulfur supply from organic-rich rocks.

Fluid inclusions hosted in huebnerite from the DCP show ${ }^{3} \mathrm{He} /{ }^{4} \mathrm{He}$ ratios that are dominated by a crustal fluid component (Fig. 10b). Leaching of uranium-bearing crustal rocks such as organic-rich sedimentary rocks or granites, which are abundant in the study area (Fig. 2), may provide the initial conditions for a higher ${ }^{4} \mathrm{He}$ production and the elevated ${ }^{4} \mathrm{He}^{40} \mathrm{Ar}^{*}$ ratio (Ozima and Podosek 2002). Organic-rich sedimentary rocks contain fixed immobile U(IV), in, e.g., U-oxides, sulfides, or carbonates, that can be efficiently leached as soluble U(VI) by circulating fluids under oxidizing conditions (Idiz et al. 1986; Granet et al. 2007; Cuney 2010). Similarly, granites and granite gneisses in the Climax and Henderson areas contain U-bearing accessories, such as zircon, monazite, or thorite (Desborough and Sharp 1978; Desborough and Mihalik 1980), and may supply mobile U due to metamictization (e.g., Romer and Cuney 2018 and references therein). The fact that both host rocks are present in the study area also makes a combined fluid-rock interaction history possible.

\section{Summary and conclusions}

Our fluid inclusion and stable isotope studies in ore and gangue minerals from various mineralization stages of the SHM provide compelling evidence that the mineralization formed from magmatic fluids and meteoric water, which mixed to different proportions with time. The evolution of ore deposition at the Sweet Home mine is shown schematically in Fig. 12.

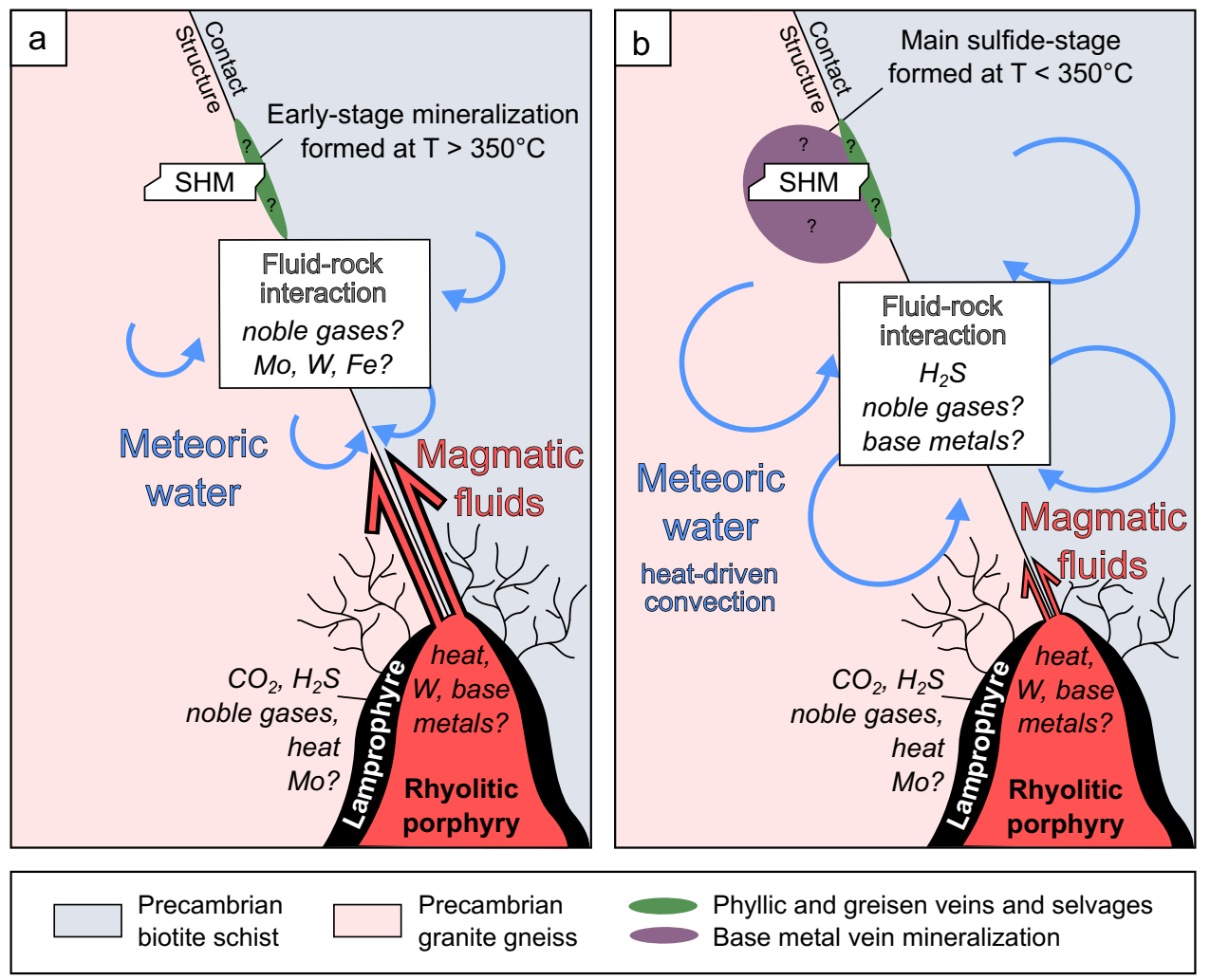

Fig. 12 Schematic model of the formation of Sweet Home mine mineralization with bimodal magmatism at depth supplying both mantle-derived volatiles (i.e., $\mathrm{CO}_{2}, \mathrm{H}_{2} \mathrm{~S}$, noble gases) and heat. Mineralization formed from magmatic fluids and meteoric water, which were mixed to different proportions with time. (a) Hot magmatichydrothermal fluids migrated along the reactivated Precambrian Contact Structure and mixed to variable proportions with meteoric water during ascent to the site of mineralization. Mixing caused fluid cool- ing and dilution of the magmatic fluids, and the deposition of greisen vein mineralization and phyllic alteration at temperatures above $350{ }^{\circ} \mathrm{C}$ (Fig. 15). (b) Heat propagation with time may have led to large-scale convection of meteoric water and leaching of sulfur (and possibly metals) from the crustal rocks. Progressive mixing led to a meteoric-dominated ore fluid and further cooling and dilution. Subsequently, polymetallic vein mineralization of the main sulfide stage formed at temperatures of less than $350{ }^{\circ} \mathrm{C}$ 
Early-stage Mo-bearing mineralization likely formed from magmatic-dominated fluids at temperatures $>400{ }^{\circ} \mathrm{C}$. Early fluid migration occurred along a reactivated Precambrian Contact Structure during N-S-trending tectonic movements (Fig. 12a). The magmatic fluids were enriched in volatiles, such as $\mathrm{CO}_{2}, \mathrm{H}_{2} \mathrm{~S} / \mathrm{SO}_{2}$, and noble gases, most likely derived from mantle sources (e.g., lamprophyric intrusion at depth). The mixing of meteoric water with magmatic fluids during the early greisen stage was minor, but increased significantly towards the main sulfide stage (Fig. 12b). Fluid mixing caused decreasing temperature and dilution of magmatic fluids. Progressive heat-driven convection of meteoric fluids may have facilitated leaching of metals from crustal rocks and led to the formation of polymetallic vein mineralization at the SHM.

Fluid mixing of magmatic fluids with large amounts of meteoric water seems the most likely mechanism for the formation of Climax-type-related peripheral vein mineralization in the CMB. The data from this study are not sufficient to determine whether Climax-type Mo mineralization in ore shells above porphyry stocks can be attributed to a similar mixing model. However, our study does show that the combination of FI studies including noble gas and stable isotope analyses with stable isotope analysis of ore and gangue minerals has the potential to answer this question.

Supplementary Information The online version contains supplementary material available at https://doi.org/10.1007/s00126-022-01102-6.

Acknowledgements We are indebted to Bryan Lees, Collector's Edge, for access to the Detroit City portal and for providing sample material. We would like to thank in particular Dean Misantoni for the fruitful discussions and for providing key samples and maps. Furthermore, we acknowledge C. Fischer and U. Dittmann for the sample preparation, C. Kusebauch for the assistance with CL imaging, and Enzio Schnabel for performing the noble gas analyses. An earlier version of this manuscript benefited from critical reviews by two anonymous Mineralium Deposita reviewers and from stylistic improvements by Marisa Repasch and Robert Trumbull.

Funding Open Access funding enabled and organized by Projekt DEAL. Our research was financed by the international research training group StRATEGy (Surface Processes, Tectonics and Georesources: The Andean foreland basin of Argentina, IGK2018) funded by the German Research Foundation (DFG) and the State of Brandenburg, Germany.

\section{Declarations}

Conflict of interest The authors declare no competing interests.

Open Access This article is licensed under a Creative Commons Attribution 4.0 International License, which permits use, sharing, adaptation, distribution and reproduction in any medium or format, as long as you give appropriate credit to the original author(s) and the source, provide a link to the Creative Commons licence, and indicate if changes were made. The images or other third party material in this article are included in the article's Creative Commons licence, unless indicated otherwise in a credit line to the material. If material is not included in the article's Creative Commons licence and your intended use is not permitted by statutory regulation or exceeds the permitted use, you will need to obtain permission directly from the copyright holder. To view a copy of this licence, visit http://creativecommons.org/licenses/by/4.0/.

\section{References}

Audétat A (2010) Source and evolution of molybdenum in the porphyry Mo $(-\mathrm{Nb})$ deposit at Cave Peak, Texas. J Petrol 51:1739-1760

Audétat A (2015) Compositional evolution and formation conditions of magmas and fluids related to porphyry Mo mineralization at Climax, Colorado. J Petrol 56:1519-1546

Audétat A, Li W (2017) The genesis of Climax-type porphyry Mo deposits: insights from fluid inclusions and melt inclusions. Ore Geol Rev 88:436-460

Audétat A, Günther D, Heinrich CA (2000) Causes for large-scale metal zonation around mineralized plutons: fluid inclusion LAICP-MS evidence from the Mole Granite, Australia. Econ Geol 95:1563-1581

Audétat A, Dolejš D, Lowenstern JB (2011) Molybdenite saturation in silicic magmas: occurrence and petrological implications. J Petrol 52:891-904

Bailey DK (1987) Mantle metasomatism—perspective and prospect In: Fitton J, Upton B (eds) Alkaline Igneous Rocks. Geol Soc London Spec Publ, pp 1-13.

Bailey DK, Macdonald R (1987) Dry peralkaline felsic liquids and carbon dioxide flux through the Kenya rift zone Magmatic Processes: Physicochemical Principles Geochem Soc Spec Publ, pp 91-105.

Bailey DK, Hampton CM (1990) Volatiles in alkaline magmatism. Lithos 26:157-165

Barbá KE, Nelson EP, Misantoni D, Hitzman MW, Layer PW (2005) Structural controls on mineralized veins in the Sweet Home Mine, Alma district, Colorado Geol Soc Nevada Symp. pp 698-708.

Barton PB, Chou I (1993) Calculation of the vapor-saturated liquidus for the $\mathrm{NaCl}-\mathrm{CO}_{2}-\mathrm{H}_{2} \mathrm{O}$ system. Geochim Cosmochim Acta 57:2715-2723

Bartos PJ, Nelson EP, Misantoni D (2007) The Sweet Home rhodochrosite specimen mine, Alma District, Central Colorado: the porphyry molybdenum-fluorine connection. Miner Deposita 42:235-250

Behre CH, Jr (1953) Geology and ore deposits of the west slope of the Mosquito Range Professional Paper 235. US Geol Surv, pp 176.

Bloom MS (1981) Chemistry of inclusion fluids; stockwork molybdenum deposits from Questa, New Mexico, Hudson Bay Mountain and Endako, British Columbia. Econ Geol 76:1906-1920

Bodnar RJ (1993) Revised equation and table for determining the freezing point depression of $\mathrm{H}_{2} \mathrm{O}-\mathrm{NaCl}$ solutions. Geochim Cosmochim Acta 57:683-684

Bodnar RJ, Reynolds TJ, Kuehn CA (1985) Fluid inclusion systematics in epithermal systems In: Berger BR, Bethke PM (eds) Geology and geochemistry of epithermal systems. Rev Econ Geol, pp 73-97.

Bookstrom AA (1981) Tectonic setting and generation of Rocky Mountain porphyry molybdenum deposits In: Dickinson W, Payne W (eds) Relations of Tectonics to Ore Deposits in the Southern Cordillera Arizona Geol Soc Digest, pp 215-226.

Bookstrom AA (1989) The Climax-Alma granite batholith of oligocene age and the prophyry molybdenum deposits of Climax, Colorado, USA. Eng Geol 27:543-568 
Bookstrom AA, Naeser CW, Shannon JR (1987) Isotopic age determinations, unaltered and hydrothermally altered igneous rocks, north-central Colorado Mineral Belt. Isochron West 49:13-20

Bookstrom AA, Carten RB, Shannon JR, Smith RP (1988) Origins of bimodal leucogranite-lamprophyre suites, Climax and Red Mountain porphyry molybdenum systems, Colorado: petrologic and strontium isotopic evidence. Colo Sch Mines Q 83:1-24

Carten RB, White WH, Stein HJ (1993) High-grade granite-related molybdenum system: classification and origin In: Kirkham R, Sinclair W, Thorpe R, Duke J (eds) Mineral deposit modeling. Geol Assoc Can Spec Pap, pp 521-554.

Carten RB, Geraghty EP, Walker BM, Shannon JR (1988) Cyclic development of igneous features and their relationship to hightemperature hydrothermal features in the Henderson porphyry molybdenum deposit, Colorado. Econ Geol 83:266-296

Chapin CE (2012) Origin of the Colorado mineral belt. Geosphere 8:28-43

Chen P, Zeng Q, Zhou T, Chen J (2021) He, Ar, and S isotopic constraints on the origin of the Dasuji porphyry Mo deposit, China. Arab J Geosci 14:1-14

Chi G, Diamond LW, Lu H, Lai J, Chu H (2021) Common problems and pitfalls in fluid inclusion study: a review and discussion. Minerals 11(1), 7:1-23.

Chicharro E, Boiron M-C, López-García JÁ, Barfod DN, Villaseca C (2016) Origin, ore forming fluid evolution and timing of the Logrosán Sn-(W) ore deposits (Central Iberian Zone, Spain). Ore Geol Rev 72:896-913

Cline JS, Bodnar RJ (1994) Direct evolution of brine from a crystallizing silicic melt at the Questa, New Mexico, molybdenum deposit. Econ Geol 89:1780-1802

Craig H (1961) Isotopic variations in meteoric waters. Science 133:1702-1703

Crovetto R, Fernández-Prini R, Japas ML (1982) Solubilities of inert gases and methane in $\mathrm{H}_{2} \mathrm{O}$ and in $\mathrm{D}_{2} \mathrm{O}$ in the temperature range of 300 to $600 \mathrm{~K}$. J Chem Physics 76:1077-1086

Cuney M (2010) Evolution of uranium fractionation processes through time: driving the secular variation of uranium deposit types. Econ Geol 105:553-569

Darling RS (1991) An extended equation to calculate $\mathrm{NaCl}$ contents from final clathrate melting temperatures in $\mathrm{H}_{2} \mathrm{O}-\mathrm{CO}_{2}-\mathrm{NaCl}$ fluid inclusions: implications for PT isochore location. Geochim Cosmochim Acta 55:3869-3871

de Graaf S, Vonhof HB, Weissbach T, Wassenburg JA, Levy EJ, Kluge T, Haug GH (2020a) A comparison of isotope ratio mass spectrometry and cavity ring-down spectroscopy techniques for isotope analysis of fluid inclusion water. Rapid Commun Mass Spectrom 34:e8837.

de Graaf S, Lüders V, Banks DA, Sośnicka M, Reijmer JJG, Kaden H, Vonhof HB (2020b) Fluid evolution and ore deposition in the Harz Mountains revisited: isotope and crush-leach analyses of fluid inclusions. Miner Deposita 55:47-62

DePaolo DJ (1981) Neodymium isotopes in the Colorado Front Range and crust-mantle evolution in the Proterozoic. Nature 291:193-196

Desborough GA, Sharp WN (1978) Tantalum, uranium, and scandium in heavy accessory oxides, Climax molybdenum mine, Climax, Colorado. Econ Geol 73:1749-1751

Desborough GA, Mihalik P (1980) Accessory minerals in the igneous host of molybdenum ore, Henderson mine, Colorado US Geol Surv Open-File Report 80-661, 19 p.

Diamond LW (1994) Introduction to phase reactions of $\mathrm{CO}_{2}-\mathrm{H}_{2} \mathrm{O}$ fluid inclusions In: De Vivo B, Frezotti ML (eds) Fluid inclusions in minerals: methods and application. Virginia Tech, Blacksburg, pp 131-158.

Gautheron C, Moreira M (2002) Helium signature of the subcontinental lithospheric mantle. Earth Planet Sci Lett 199:39-47
Geissman JW, Snee LW, Graaskamp GW, Carten RB, Geraghty EP (1992) Deformation and age of the Red Mountain intrusive system (Urad-Henderson molybdenum deposits), Colorado: Evidence from paleomagnetic and ${ }^{40} \mathrm{Ar} /{ }^{39} \mathrm{Ar}$ data. Geol Soc Am Bull 104:1031-1047

Goldstein HR, Reynolds TJ (1994) Systematics of fluid inclusions in diagenetic minerals. SEPM Short Course 31:1-199

Graham DW (2002) Noble gas isotope geochemistry of mid-ocean ridge and ocean island basalts: characterization of mantle source reservoirs. Rev Mineral Geochem 47:247-317

Granet M, Chabaux F, Stille P, France-Lanord C, Pelt E (2007) Timescales of sedimentary transfer and weathering processes from U-series nuclides: clues from the Himalayan rivers. Earth Planet Sci Lett 261:389-406

Hall WE, Friedman I, Nash JT (1974) Fluid inclusion and light stable isotope study of the Climax molybdenum deposits, Colorado. Econ Geology 69:884-901

Heinrich CA, Ryan CG, Mernagh TP, Eadington PJ (1992) Segregation of ore metals between magmatic brine and vapor; a fluid inclusion study using PIXE microanalysis. Econ Geol $87: 1566-1583$

Hoefs J (2018) Stable isotope geochemistry. Springer International Publishing AG.

Honda M, McDougall I, Patterson DB, Doulgeris A, Clague DA (1991) Possible solar noble-gas component in Hawaiian basalts. Nature 349:149-151

Honma H, Itihara Y (1981) Distribution of ammonium in minerals of metamorphic and granitic rocks. Geochim Cosmochim Acta 45:983-988

Hünemohr H (1989) Edelgase in U-und Th-reichen Mineralen und die Bestimmung der ${ }^{21} \mathrm{Ne}$-Dicktarget-Ausbeute der ${ }^{18} \mathrm{O}(\alpha, \mathrm{n}){ }^{21} \mathrm{Ne}$ Kernreaktion im Bereich 4.0-8.8 MeV. PhD thesis, JohannesGutenberg Universität Mainz.

Idiz EF, Carlisle D, Kaplan IR (1986) Interaction between organic matter and trace metals in a uranium rich bog, Kern County, California, USA. Appl Geochem 1:573-590

Jia Y, Kerrich R (1999) Nitrogen isotope systematics of mesothermal lode gold deposits: metamorphic, granitic, meteoric water, or mantle origin? Geology 27:1051-1054

Johansing RJ, Thompson T, Skinner B, Landis G (1990) Geology and origin of Sherman-Type deposits, Central Colorado. Discussion and reply. In: Carbonate-Hosted Sulfide Deposits of the Central Colorado Mineral Belt. Soc Econ Geol Monogr 7: 367-406.

Keith JD, Christiansen EH, Carten RB (1993) The genesis of giant porphyry molybdenum deposits In: Hodgson C, Mason R, Whiting B (eds) Giant Ore Deposits. Soc Econ Geol Spec Publ 2: 285-316

Kelley KD, Romberger SB, Beaty DW, Pontius JA, Snee LW, Stein HJ, Thompson TB (1998) Geochemical and geochronological constraints on the genesis of Au-Te deposits at Cripple Creek, Colorado. Econ Geol 93:981-1012

Kendrick MA, Burgess R, Pattrick RAD, Turner G (2001) Fluid inclusion noble gas and halogen evidence on the origin of $\mathrm{Cu}$-porphyry mineralising fluids. Geochim Cosmochim Acta 65:2651-2668

Klemm LM, Pettke T, Heinrich CA (2008) Fluid and source magma evolution of the Questa porphyry Mo deposit, New Mexico, USA. Miner Deposita 43:533

Lee J-Y, Marti K, Severinghaus JP, Kawamura K, Yoo H-S, Lee JB, Kim JS (2006) A redetermination of the isotopic abundances of atmospheric Ar. Geochim Cosmochim Acta 70:4507-4512

Lipman PW, Mehnert HH (1975) Late Cenozoic basaltic volcanism and development of the Rio Grande depression in the southern Rocky Mountains. Geol Soc Am Mem 144:119-154

Lowenstern JB (1994) Dissolved volatile concentrations in an oreforming magma. Geology 22:893-896 
Lowenstern JB (2001) Carbon dioxide in magmas and implications for hydrothermal systems. Miner Deposita 36:490-502

Lüders V (2017) Contribution of infrared microscopy to studies of fluid inclusions hosted in some opaque ore minerals: possibilities, limitations, and perspectives. Miner Deposita 52:663-673

Lüders V, Ziemann M (1999) Possibilities and limits of infrared light microthermometry applied to studies of pyrite-hosted fluid inclusions. Chem Geol 154:169-178

Lüders V, Plessen B (2015) Stable carbon isotope ratios of $\mathrm{CH}_{4}$-rich gas inclusions in shale-hosted fracture-fill mineralization: a tool for tracing hydrocarbon generation and migration in shale plays for oil and gas. Marine Petrol Geol 63:68-81

Lüders V, Plessen B, di Primio R (2012) Stable carbon isotopic ratios of $\mathrm{CH}_{4}-\mathrm{CO}_{2}$-bearing fluid inclusions in fracture-fill mineralization from the Lower Saxony Basin (Germany)-a tool for tracing gas sources and maturity. Marine Petrol Geol 30:174-183

Lüders V, Romer RL, Gilg HA, Bodnar RJ, Pettke T, Misantoni D (2009) A geochemical study of the Sweet Home Mine, Colorado Mineral Belt, USA: hydrothermal fluid evolution above a hypothesized granite cupola. Miner Deposita 44:415-434

Ludington S, Plumlee GS (2009) Climax-type porphyry molybdenum deposits. US Geol Surv Open-File Report 2009-1215:1-16

Markey R, Stein HJ, Hannah JL, Zimmerman A, Selby D, Creaser RA (2007) Standardizing Re-Os geochronology: a new molybdenite reference material (Henderson, USA) and the stoichiometry of Os salts. Chem Geol 244:74-87

McCalpin JP, Temple J, Sicard K, Mendel D, Ahmad B (2012) Climax Quadrangle Geologic map, Lake and Park Counties, Colorado. Colorado Geol Surv Open-File Report 12-09.

Mercer CN, Hofstra AH, Todorov TI, Roberge J, Burgisser A, Adams DT, Cosca M (2015) Pre-eruptive conditions of the Hideaway Park topaz rhyolite: insights into metal source and evolution of magma parental to the Henderson porphyry molybdenum deposit, Colorado. J Petrol 56:645-679

Mingram B, Bräuer K (2001) Ammonium concentration and nitrogen isotope composition in metasedimentary rocks from different tectonometamorphic units of the European Variscan Belt. Geoch Cosmochim Acta 65:273-287

Misantoni D, Silberman ML, Lees BK (1998) Geology of the Sweet Home mine and Alma district. Mineralogical Record 29(4):101-114

Mutschler FE, Wright EG, Ludington S, Abbott JT (1981) Granite molybdenite systems. Econ Geol 76:874-897

Niedermann S, Bach W, Erzinger J (1997) Noble gas evidence for a lower mantle component in MORBs from the southern East Pacific Rise: Decoupling of helium and neon isotope systematics. Geochim Cosmochim Acta 61:2697-2715

Ohmoto H, Rye RO (1979) Isotopes of sulfur and carbon. In: Barnes H (ed) Geochemistry of hydrothermal ore deposits, 3rd edn. Wiley, New York, pp 509-567

Ohmoto H, Lasaga AC (1982) Kinetics of reactions between aqueous sulfates and sulfides in hydrothermal systems. Geochim Cosmochim Acta 46:1727-1745

Ozima M, Igarashi G (2000) The primordial noble gases in the Earth: a key constraint on Earth evolution models. Earth Planet Sci Lett 176:219-232

Ozima M, Podosek FA (2002) Noble gas geochemistry. Cambridge University Press

Papale P, Polacci M (1999) Role of carbon dioxide in the dynamics of magma ascent in explosive eruptions. Bull Volcanol 60:583-594

Pettke T, Oberli F, Heinrich CA (2010) The magma and metal source of giant porphyry-type ore deposits, based on lead isotope microanalysis of individual fluid inclusions. Earth Planet Sci Lett 296:267-277
Plessen B, Lüders V (2012) Simultaneous measurements of gas isotopic compositions of fluid inclusion gases $\left(\mathrm{N}_{2}, \mathrm{CH}_{4}, \mathrm{CO}_{2}\right)$ using continuous-flow isotope ratio mass spectrometry. Rapid Commun Mass Spectrometry 26:1157-1161

Pöter B, Gottschalk M, Heinrich W (2004) Experimental determination of the ammonium partitioning among muscovite, K-feldspar, and aqueous chloride solutions. Lithos 74:67-90

Reynolds TJ (1998) Ancient fluids at the Sweet Home mine. Mineral Record 29(4):127-134

Roedder E (1984) Fluid inclusions. Miner Soc Am Rev Mineral 12:1-644

Romer RL, Lüders V (2006) Direct dating of hydrothermal W mineralization: $\mathrm{U}-\mathrm{Pb}$ age for hübnerite $\left(\mathrm{MnWO}_{4}\right)$, Sweet Home Mine, Colorado. Geochim Cosmochim Acta 70:4725-4733

Romer RL, Cuney M (2018) Phanerozoic uranium mineralization in Variscan Europe-more than $400 \mathrm{Ma}$ of tectonic, supergene, and climate-controlled uranium redistribution. Ore Geol Rev 102:474-504

Rowe A (2012) Ore genesis and fluid evolution of the Goat Hill Orebody, Questa Climax-type Porphyry-Mo System, NM and its comparison to the Climax-type deposits of the Colorado Mineral Belt. PhD thesis, New Mexico Inst Min Technol, Socorro, New Mexico.

Russell LR, Snelson S (1994) Structure and tectonics of the Albuquerque basin segment of the Rio Grande rift: insights from reflection seismic data. Geol Soc Am Spec Pap 291:83-112

Rye RO, O'Neil JR (1968) The O18 content of water in primary fluid inclusions from Providencia, north-central Mexico. Econ Geol 63:232-238

Sarda P, Staudacher T, Allègre CJ (1988) Neon isotopes in submarine basalts. Earth Planet Sci Lett 91:73-88

Scaillet B, Pichavant M (2005) A model of sulphur solubility for hydrous mafic melts: application to the determination of magmatic fluid compositions of Italian volcanoes. Annals Geophysics 48:671-698

Seedorff E, Einaudi MT (2004a) Henderson porphyry molybdenum system, Colorado: I. Sequence and abundance of hydrothermal mineral assemblages, flow paths of evolving fluids, and evolutionary style. Econ Geol 99:3-37

Seedorff E, Einaudi MT (2004b) Henderson porphyry molybdenum system, Colorado: II. Decoupling of introduction and deposition of metals during geochemical evolution of hydrothermal fluids. Econ Geol 99:39-72

Shannon JR, Nelson EP, Golden RJ (2004) Surface and underground geology of the world-class Henderson molybdenum porphyry mine, Colorado In: Nelson E, Erslev E (eds) Field Trips in the Southern Rocky Mountains, USA. Geol Soc Am, Field Guide 5, pp 207-218.

Sheppard SMF (1986) Characterization and isotope variations in natural waters. Rev Mineral 16:165-183

Smith RW (1983) Aqueous chemistry of molybdenum at elevated temperatures and pressures with applications to porphyry molybdenum deposits. PhD thesis, New Mexico Inst Min Technol, Socorro, New Mexico, $324 \mathrm{p}$.

Smith SP, Kennedy BM (1983) The solubility of noble gases in water and in $\mathrm{NaCl}$ brine. Geochim Cosmochim Acta 47:503-515

Steele-MacInnis M (2018) Fluid inclusions in the system $\mathrm{H}_{2} \mathrm{O}-\mathrm{NaCl}-\mathrm{CO}_{2}$ : An algorithm to determine composition, density and isochore. Chem Geol 498:31-44

Steele-MacInnis M, Lecumberri-Sanchez P, Bodnar RJ (2012) Short note: HokieFlincs_H2O-NaCl: a Microsoft Excel spreadsheet for interpreting microthermometric data from fluid inclusions based on the PVTX properties of $\mathrm{H}_{2} \mathrm{O}-\mathrm{NaCl}$. Comput Geosci 49:334-337 
Stein HJ (1988) Genetic traits of Climax-type granites and molybdenum mineralisation, Colorado Mineral Belt In: Taylor R, Strong D (eds) Recent Advances in the Geology of Granite-Related Mineral Deposits Can Inst Min Metal Spec Vol 39. pp 394-401.

Stein HJ, Hannah JL (1985) Movement and origin of ore fluids in Climax-type systems. Geology 13:469-474

Sterner SM, Bodnar RJ (1984) Synthetic fluid inclusions in natural quartz I. Compositional types synthesized and applications to experimental geochemistry. Geochim Cosmochim Acta 48:2659-2668

Taylor HP Jr (1974) The application of oxygen and hydrogen isotope studies to problems of hydrothermal alteration and ore deposition. Econ Geol 69:843-883

Theobald PK, Eppinger RG, Moss CK, Barton HN, Bielski AM, Kreidler TJ (1983) Mineral resource potential map of the Vasquez Peak Wilderness Study Area, and the St. Louis Peak and Williams Fork Roadless Areas, Clear Creek, Grand, and Summit counties, Colorado. US Geol Surv Miscellaneous Field Studies Map MF-1588-A.

Thompson TB, Arehart GB (1990) Geology and the origin of ore deposits in the Leadville district, Colorado: Part I. Geologic studies of orebodies and wall rocks In: Beaty DW, Landis GP, Thompson TB (eds) Carbonate-Hosted Sulfide Deposits of the Central Colorado Mineral Belt: . Econ Geol Monograph 7, pp 130-155.

Tweto O, Sims PK (1963) Precambrian ancestry of the Colorado mineral belt. Geol Soc Am Bull 74:991-1014

Tweto OL (1960) Scheelite in the Precambrian gneisses of Colorado. Econ Geol 55:1406-1428

Uemura R, Kina Y, Shen C-C, Omine K (2020) Experimental evaluation of oxygen isotopic exchange between inclusion water and host calcite in speleothems. Climate Past 16:17-27

Wallace PJ, Edmonds M (2011) The sulfur budget in magmas: evidence from melt inclusions, submarine glasses, and volcanic gas emissions. Rev Mineral Geochem 73:215-246

Wallace S, Bookstrom A (1993) The Climax porphyry molybdenum system. Colo Sch Mines Q 93:35-41

Wallace SR (1995) The Climax-type molybdenite deposits: what they are, where they are and why they are. Econ Geol 90:1359-1380

Wallace SR, MacKenzie WB, Blair RG, Muncaster NK (1978) Geology of the Urad and Henderson molybdenite deposits, Clear Creek County, Colorado, with a section on a comparison of these deposits with those at Climax, Colorado. Econ Geol 73:325-368
Wallace SR, Muncaster NK, Jonson DC, MacKenzie WB, Bookstrom AA, Surface VE (1968) Multiple intrusion and mineralization at Climax, Colorado. Ore Deposits United States 1:605-640

Wang L, Tang J, Cheng W, Chen W, Zhang Z, Lin X, Luo M, Yang C (2015) Origin of the ore-forming fluids and metals of the Bangpu porphyry $\mathrm{Mo}-\mathrm{Cu}$ deposit of Tibet, China: constraints from $\mathrm{He}-$ $\mathrm{Ar}, \mathrm{H}-\mathrm{O}, \mathrm{S}$ and $\mathrm{Pb}$ isotopes. J Asian Earth Sci 103:276-287

Westra G, Keith SB (1981) Classification and genesis of stockwork molybdenum deposits. Econ Geol 76:844-873

White WH, Bookstrom AA, Kamilli RJ, Ganster MW, Smith RP, Ranta DE, Steininger RC (1981) Character and origin of Climax-type molybdenum deposits. Econ Geol 75:270-316

Widmann BL, Bartos PJ, Madole RF, Barbá KE, Moll ME (2004) Geologic Map of the Alma Quadrangle, Park and Summit Counties, Colorado. Colorado Geol Surv Open-File Rep:04-03.

Xiong X, Zhu L, Zhang G, Li N, Yuan H, Ding L, Sun C, Guo A (2018) Fluid inclusion geochemistry and magmatic oxygen fugacity of the Wenquan Triassic molybdenum deposit in the Western Qinling Orogen, China. Ore Geol Rev 99:244-263

Yang Y-F, Chen Y-J, Pirajno F, Li N (2015) Evolution of ore fluids in the Donggou giant porphyry Mo system, East Qinling, China, a new type of porphyry Mo deposit: evidence from fluid inclusion and H-O isotope systematics. Ore Geol Rev 65:148-164

Zahony S (1968) Chemical controls of molybdenum ore formation. Unpubl report, Climax Molybdenum Co, p 20

Zeng Q, Guo W, He H, Zhou L, Cheng G, Su F, Wang Y, Wang R (2018) He, Ar, and S isotopic compositions and origin of giant porphyry Mo deposits in the Lesser Xing' an Range-Zhangguangcai Range metallogenic belt, northeast China. J Asian Earth Sci 165:228-240

Zhang F-F, Wang Y-H, Liu J-J (2016) Fluid inclusions and $\mathrm{H}-\mathrm{O}-\mathrm{S}-\mathrm{Pb}$ isotope systematics of the Baishan porphyry Mo deposit in Eastern Tianshan, China. Ore Geol Rev 78:409-423

Zhou L-1, Zeng Q-d, Liu J-m, Friis H, Zhang Z-1, Duan X-x, Chu S-x (2015) Ore genesis and fluid evolution of the Daheishan giant porphyry molybdenum deposit, NE China. J Asian Earth Sci 97:486-505

Publisher's note Springer Nature remains neutral with regard to jurisdictional claims in published maps and institutional affiliations. 